\title{
1. EXMOUTH PLATEAU REVISITED: SCIENTIFIC DRILLING AND GEOLOGICAL FRAMEWORK ${ }^{1}$
}

\author{
N. F. Exon, ${ }^{2}$ B. U. Haq, ${ }^{3}$ and U. von $\operatorname{Rad}^{4}$
}

\begin{abstract}
The Exmouth Plateau is a very large marginal plateau containing $10 \mathrm{~km}$ of Phanerozoic sediments and is underlain by continental crust that was stretched and thinned, probably in the Late Permian. For much of the Mesozoic it was part of the northern shore of eastern Gondwana and the southern shore of Tethys, and a large part of the Phanerozoic sequence consists of Triassic fluviodeltaic sediments. Late Triassic to Late Jurassic rifting caused block-faulting, and several large grabens have a thick fill of Jurassic shallow-marine carbonates and coal-measure sequences.

A major post-rift unconformity, of a minimum Callovian-Oxfordian age, is commonly directly overlain at the Valanginian breakup unconformity by Neocomian transgressive marine sediments, whose character is controlled by the breakup history of the plateau margins. A microcontinent broke away from the northern margin in the Late Jurassic, leaving behind the oceanic crust of the Argo Abyssal Plain. Greater India broke away from the northwestern and southwestern margins of the plateau in the late Valanginian, leaving behind the oceanic crust of the Gascoyne and Cuvier abyssal plains.

After breakup, the Exmouth Plateau was surrounded by abyssal plains on three sides, so terrigenous input greatly decreased. As the plateau sank, shallow-marine Early Cretaceous sedimentation gave way slowly to bathyal carbonate sedimentation. Slow sedimentation rates resulted in a Cretaceous-Cenozoic sequence above the post-rift unconformity that is very thin by global standards, so that the plateau is an ideal area to study the pre-rift and rift sequences by geophysical methods, dredging, and drilling.

The plateau has been extensively studied by academia, government agencies, and the petroleum industry, and has a vast open file and proprietary data set. In 1988, the Ocean Drilling Program drilled at six sites on the plateau during Leg 122 and two sites on the adjacent abyssal plains during Leg 123, designed to address the geological history of this continental margin, as an exemplar for other, more heavily sedimented margins. The six Exmouth Plateau holes cored a total of $3370 \mathrm{~m}$ of Upper Triassic, Cretaceous, and Cenozoic strata, with excellent recovery in all but Upper Triassic carbonates. This paper introduces the results contained in 55 papers included in this volume, covering most aspects of passive margin evolution and paleoenvironment, biostratigraphy, magnetostratigraphy, chemostratigraphy, sequence stratigraphy, rift tectonics, eustatic sea-level fluctuations, cyclic sedimentation, and orbital forcing. This paper also outlines the paleogeographic development of the region from Late Triassic to Albian times.
\end{abstract}

\section{INTRODUCTION}

The northwestern Australian margin is one of the world's oldest continental margins. Because there is relatively little post-breakup sediment on its marginal plateaus, it is an ideal area for drill studies of pre-rift, rift, and early post-rift geological history. The margin's tectonic history and paleogeographic evolution are well reviewed by Veevers (1988) and Bradshaw et al. (1988). Ocean Drilling Program (ODP) Legs 122 and 123 were drilled in the Exmouth Plateau area in 1988: Sites $759,760,761,764$, and 765 form a north-south transect across the Wombat Plateau and Argo Abyssal Plain, and Sites 762,763 , and 766 form an east-west transect across the central Exmouth Plateau and the Gascoyne Abyssal Plain.

The Exmouth Plateau is about $600 \mathrm{~km}$ long and $300-400 \mathrm{~km}$ wide, with water depths of $800-4000 \mathrm{~m}$. The plateau consists of stretched, rifted, and subsided continental crust about 20 $\mathrm{km}$ thick, including about $10 \mathrm{~km}$ of little-deformed Phanerozoic sedimentary rocks. It is separated from the Australian

\footnotetext{
${ }^{1}$ von Rad, U., Haq, B. U., et al., 1992. Proc. ODP, Sci. Results, 122: College Station, TX (Ocean Drilling Program).

2 Bureau of Mineral Resources, GPO Box 378, Canberra 2601, Australia.

3 National Science Foundation, 1800 G Street NW, Washington, DC 20550, U.S.A.

${ }^{4}$ Bundesanstalt für Geowissenschaften und Rohstoffe, Postfach 510153, D-3000 Hannover 51, Federal Republic of Germany.
}

Northwest Shelf by the Kangaroo Syncline, which lies between the two $1000-\mathrm{m}$ bathymetric contours in Figure 1. The plateau is bounded to the north, west, and south by the oceanic crust of the Argo, Gascoyne, and Cuvier abyssal plains. The plateau is regarded as part of the northern Carnarvon Basin by Cockbain (1989), and its sediments are continuous with those of the remainder of the northern Carnarvon Basin to the southeast, and the Canning Basin to the east (Willcox and Exon, 1976; Powell, 1976; Exon and Willcox, 1978, 1980; Exon et al., 1982; Exon and Williamson, 1988; Barber, 1982, 1988; Hocking et al., 1987, 1988; Horstmann and Purcell, 1988; Boote and Kirk, 1989; von Rad et al., 1989; Haq, von Rad, O'Connell, et al., 1990).

The adjacent abyssal plains formed in two stages, the Argo Abyssal Plain in the latter part of the Jurassic to the earliest Neocomian, and the Gascoyne and Cuvier abyssal plains in the Valanginian to Barremian (Markl, 1974; Veevers, Heirtzler, et al., 1974; Larson, 1977; Larson et al., 1979; Heirtzler et al., 1978; Fullerton et al., 1989; Ludden, Gradstein, et al., 1990; Sager et al., in press). The Argo Abyssal Plain, about $5700 \mathrm{~m}$ deep, is underlain by the oldest oceanic crust in the Indian Ocean (155-Ma oceanic crust, J. Ludden, pers. comm., 1991; overlain by Tithonian to Berriasian sediments according to Ludden, Gradstein, et al., 1990;) and is being subducted at the Java Trench. The Gascoyne Abyssal Plain is also up to $5700 \mathrm{~m}$ deep, but the Cuvier Abyssal Plain is not deeper than $5070 \mathrm{~m}$ (e.g., Falvey and Veevers, 1974). 


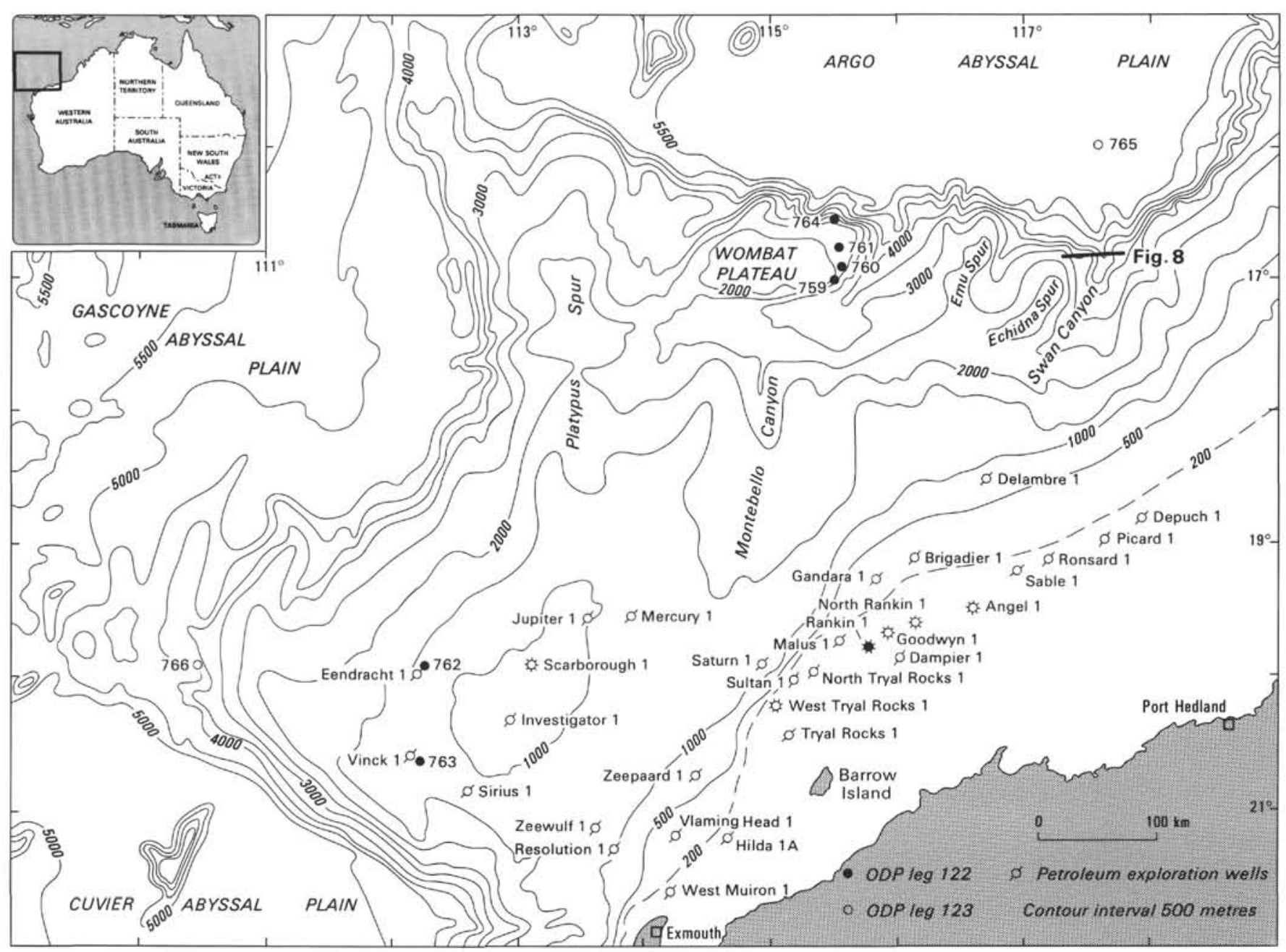

Figure 1. Map of the Exmouth Plateau showing bathymetry, ODP sites, petroleum exploration wells, and location of Figure 8. Exploration wells display standard petroleum industry symbols.

The Exmouth Plateau to Argo Abyssal Plain transect was the first ODP investigation of a Mesozoic, sediment-starved passive margin since the 1985 drilling of the Galicia margin (Leg 103; see Boillot, Winterer, et al., 1987). Drilling the transect allows: (1) comparison of tectonic and seismic sequences with Atlantic passive margins, (2) refinement of the Mesozoic geological time scale, and (3) characterization of old oceanic crust prior to subduction at the Java Trench.

The Exmouth Plateau can serve as a model for an old, sediment-starved (less than $2 \mathrm{~km}$ of post-breakup sediments), passive continental margin with a broad continent/ocean transition. The unusually wide marginal plateau between the shelf and the old Indian Ocean crust allows study of the structural development of the ocean/continent transition, and testing of various tectonic models by geophysical methods and core analysis. The thin post-rift cover and the varied paleo-water depths $(0-4000 \mathrm{~m})$ make it a prime target for detailed studies of biostratigraphy, sediment facies, paleoenvironment, and stratigraphic evolution, because of the interplay between subsidence and sea-level fluctuations.

Leg 122 was planned using drilling proposals by von Rad et al. (1984), von Rad et al. (1986), Arthur et al. (1986), and Mutter and Larson (1987). Additional drilling proposals for alternative locations for Sites 762 and 763 , based on industry multichannel seismic and well-log data in the region, were presented by Haq and Boyd in 1988 . We also relied heavily on pre-site survey information in the cruise reports of Sonne cruise SO-8 (von Stackelberg et al., 1980) and Rig Seismic cruises 55 and 56 (Williamson and Falvey, 1988; Exon and Williamson, 1988). Basic information on the ODP sites is provided in Table 1, and on nearby Deep Sea Drilling Project (DSDP) sites in Table 2. The Haq et al. (1987) time scale is used throughout this volume.

\section{BACKGROUND}

\section{Stratigraphy and Tectonics}

The stratigraphy of the Carnarvon Basin to the east of the Exmouth Plateau has been detailed by Hocking et al. (1987). The general stratigraphy of the Exmouth Plateau (part of the northern Carnarvon Basin) was first defined by Willcox and Exon (1976) and Exon and Willcox $(1978,1980)$, on the basis of Northwest Shelf wells and geophysical profiles across the plateau. This was refined by dredging on the plateau margin (von Stackelberg et al., 1980; von Rad and Exon; 1983; von Rad et al., 1990), and by exploration company geophysical surveys and drilling on the plateau (Wright and Wheatley, 1979; Barber, 1982, 1988; Erskine and Vail, 1988). The generalized stratigraphy of the central Exmouth Plateau (near ODP Sites 762 and 763), and on the northern margin of the plateau, is shown in Figure 2. For much of its history, the Carnarvon 
Table 1. Site data from ODP Legs 122 and 123.

\begin{tabular}{|c|c|c|c|c|c|}
\hline Site & $\begin{array}{l}\text { Latitude } \\
\quad\left({ }^{\circ} \mathrm{S}\right)\end{array}$ & $\begin{array}{l}\text { Longitude } \\
\left({ }^{\circ} \mathrm{S}\right)\end{array}$ & $\begin{array}{l}\text { Water } \\
\text { depth } \\
\text { (m) }\end{array}$ & $\begin{array}{l}\text { Total } \\
\text { depth } \\
\text { (mbsf) }\end{array}$ & $\begin{array}{l}\text { Oldest rocks } \\
\text { drilled }\end{array}$ \\
\hline 759 & $16^{\circ} 57.25^{\prime}$ & $115^{\circ} 33.61^{\prime}$ & 2091.6 & 308 & $\begin{array}{l}\text { Carnian siltstone and } \\
\text { claystone }\end{array}$ \\
\hline 760 & $16^{\circ} 55.32^{\prime}$ & $115^{\circ} 32.48^{\prime}$ & 1969.7 & 506 & $\begin{array}{l}\text { Norian sandstone, siltstone } \\
\text { and claystone }\end{array}$ \\
\hline 761 & $16^{\circ} 44.23^{\prime}$ & $115^{\circ} 32.10^{\prime}$ & 2188.8 & 287 & $\begin{array}{l}\text { Rhaetian carbonate } \\
\text { wackestone and packstone }\end{array}$ \\
\hline 764 & $16^{\circ} 33.96^{\prime}$ & $115^{\circ} 27.43^{\prime}$ & 2698.6 & 294 & $\begin{array}{l}\text { Rhaetian clayey carbonate } \\
\text { mudstone }\end{array}$ \\
\hline 762 & $19^{\circ} 53.23^{\prime}$ & $112^{\circ} 15.24^{\prime}$ & 1359.9 & 940 & Berriasian silty claystone \\
\hline 763 & $20^{\circ} 35.20^{\prime}$ & $112^{\circ} 12.50^{\prime}$ & 1367.5 & 1037 & Berriasian silty claystone \\
\hline 765 & $15^{\circ} 58.54^{\prime}$ & $117^{\circ} 34.49^{\prime}$ & 5721.4 & 964 & $\begin{array}{l}\text { Tithonian-Berriasian } \\
\text { siltstone over oceanic } \\
\text { pillow basalt. Basalt } 155 \\
\text { Ma (J. Ludden, pers. } \\
\text { comm., 1991). }\end{array}$ \\
\hline 766 & $19^{\circ} 55.92^{\prime}$ & $110^{\circ} 27.24^{\prime}$ & 4535.2 & 527 & $\begin{array}{l}\text { Valanginian sandstone and } \\
\text { siltstone over tholeiitic } \\
\text { basalt sill }\end{array}$ \\
\hline
\end{tabular}

Basin formed part of the southern shore of the Tethyan Ocean, whose complex history is outlined by S̨engör (1985).

Willcox and Exon (1976) showed that the Exmouth Plateau consists of crust about $20 \mathrm{~km}$ thick, with approximately half that thickness being Phanerozoic sediments. The oldest sedimentary rocks drilled or dredged are Upper Triassic, and the oldest volcanic rocks recovered are uppermost Triassic (Fig. 2). However, there is a considerable unsampled sedimentary
Table 2. Site data from DSDP Leg 27 off western Australia.

\begin{tabular}{|c|c|c|c|c|c|}
\hline Site & $\begin{array}{l}\text { Latitude } \\
\left({ }^{\circ} \mathrm{S}\right)\end{array}$ & $\begin{array}{l}\text { Longitude } \\
\left.\text { ( }{ }^{\circ} \mathrm{E}\right)\end{array}$ & $\begin{array}{l}\text { Water } \\
\text { depth } \\
\text { (m) }\end{array}$ & $\begin{array}{l}\text { Total } \\
\text { depth } \\
\text { (mbsf) }\end{array}$ & $\begin{array}{l}\text { Oldest rocks } \\
\text { drilled }\end{array}$ \\
\hline 259 & $29^{\circ} 37.05^{\prime}$ & $112^{\circ} 41.78^{\prime}$ & 4696 & 346 & $\begin{array}{l}\text { Neocomian-Aptian claystone } \\
\text { over altered tholeiitic basalt } \\
\text { flows. }\end{array}$ \\
\hline 260 & $16^{\circ} 08.67^{\prime}$ & $110^{\circ} 17.92^{\prime}$ & 5702 & 331 & $\begin{array}{l}\text { Middle Albian clay over } \\
\text { tholeiitic basalt sill. }\end{array}$ \\
\hline 261 & $12^{\circ} 56.83^{\prime}$ & $117^{\circ} 53.56^{\prime}$ & 5667 & 579.5 & $\begin{array}{l}{ }^{\text {a }} \text { Kimmeridgian/Tithonian clay } \\
\text { over } 10 \mathrm{~m} \text { tholeitic basalt } \\
\text { sill, over tholeiitic basalt } \\
\text { flows. }\end{array}$ \\
\hline 263 & $23^{\circ} 19.43^{\prime}$ & $110^{\circ} 58.81^{\prime}$ & 5048 & 746 & $\begin{array}{l}\text { Hauterivian(?) to Albian(?) } \\
\text { quartz-bearing clay; seismic } \\
\text { profile suggests hole stopped } \\
\text { a few meters above acoustic } \\
\text { basement (oceanic basalt). }\end{array}$ \\
\hline
\end{tabular}

a Reexamined and reassessed by paleontologists from Leg 123 (formerly dated as Callovian).

section between these Upper Triassic rocks and acoustic basement; we speculate that the unidentified section is largely Permo-Triassic in age. Typical cross-sections across the western and northern margins, derived from conventional multichannel seismic profiling and other information, are shown in Figures 3 and 4.

A two-ship, deep seismic reflection/refraction experiment, carried out jointly across the central and southern Exmouth Plateau by the Australian Bureau of Mineral Resources

\begin{tabular}{|c|c|c|c|c|c|c|c|c|c|c|}
\hline & \multirow{2}{*}{\multicolumn{3}{|c|}{ Age (m.y.) }} & \multirow{2}{*}{$\begin{array}{l}\text { Reflect/ } \\
\text { Symbol }\end{array}$} & \multicolumn{3}{|c|}{ NORTH EXMOUTH PLATEAU } & \multicolumn{3}{|c|}{ EXMOUTH PLATEAU PROPER } \\
\hline & & & & & Sequence & Thick (m) & Environment & Sequence & Thick (m) & Environment \\
\hline \multirow{4}{*}{-20} & \multicolumn{3}{|r|}{ PLEISTOCENE } & \multirow{4}{*}{ Mioc } & & \multirow{3}{*}{$200-400$} & \multirow{3}{*}{\multicolumn{2}{|c|}{$\begin{array}{c}\text { Miocene to Recent } \\
\text { pelagic ooze and chalk }\end{array}$}} & \multirow{3}{*}{$200-400$} & \multirow{11}{*}{$\begin{array}{l}\text { Mature ocean, } \\
\text { carbonate } \\
\text { deposition }\end{array}$} \\
\hline & \multirow{2}{*}{ 을 } & \begin{tabular}{|l|l|} 
Iate \\
middl \\
\end{tabular} & PLIOCENE & & Miocene to Recent & & & & & \\
\hline & & early & & & & & & & & \\
\hline & O & lato & & & & & \multirow{8}{*}{$\begin{array}{l}\text { Mature ocean, } \\
\text { carbonate } \\
\text { deposition }\end{array}$} & & & \\
\hline \multirow{3}{*}{-40} & อ & \begin{tabular}{|l|l|l} 
early \\
\end{tabular} & & & & & & & & \\
\hline & o & late & & & & & & & & \\
\hline & 웄 & \begin{tabular}{|l|l|} 
middl \\
oarly
\end{tabular} & & Eoc & Eocene chalk & $100-200$ & & Eocene chalk & $200-600$ & \\
\hline \multirow{2}{*}{-60} & - & \begin{tabular}{|l|l|} 
late \\
\end{tabular} & & \multirow{5}{*}{$\begin{array}{c}\mathrm{B} I \\
\mathrm{~B}\end{array}$} & & & & & & \\
\hline & 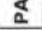 & \begin{tabular}{|l|} 
early \\
\end{tabular} & & & 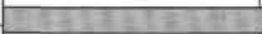 & 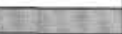 & & +2 & 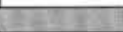 & \\
\hline \multirow[t]{2}{*}{80} & \multirow{6}{*}{ 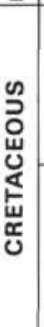 } & \multirow{3}{*}{ ฮ્ّ } & \begin{tabular}{|l|l|} 
& \multicolumn{2}{|l}{ Maastrichtian } \\
& Campanian \\
\cline { 2 - 3 } & Santonian \\
\cline { 2 - 3 } & Coniacian \\
\end{tabular} & & $\begin{array}{c}\text { Late Cretaceous } \\
\text { carbonates and marls }\end{array}$ & $50-100$ & & $\begin{array}{l}\text { Late Cretaceous shelf } \\
\text { carbonates and marls }\end{array}$ & $50-400$ & \\
\hline & & & $-\infty \frac{1}{\text { Turonian }}$ & & 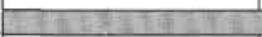 & 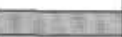 & & 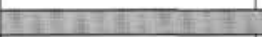 & 3 & \\
\hline \multirow{3}{*}{-100} & & & Cenomanian & & Middle Cretaceous & \multirow{2}{*}{$100-200$} & \multirow{2}{*}{$\begin{array}{c}\text { Transition } \\
\text { juvenile-mature }\end{array}$} & \multirow{3}{*}{$\begin{array}{l}\text { Middle Cretaceous } \\
\text { shallow marine shale }\end{array}$} & \multirow{3}{*}{$200-400$} & Transition \\
\hline & & \multirow{4}{*}{ 莺 } & Albian & \multirow{4}{*}{$\mathrm{Km}$} & shallow marine shale & & & & & juvenile-mature \\
\hline & & & Aptian & & & & & & & Juvenile ocean \\
\hline-120 & & & Neocomian. & & & & Juvenile ocean & & & Dreakup priva \\
\hline-140 & & & Tithonian & & $\begin{array}{c}\text { Condensed transgr } \\
\text { sand/calcisiltite nan } \\
\text { Breakup }\end{array}$ & $\begin{array}{l}\text { essive } \\
\text { no chalk }\end{array}$ & & $\begin{array}{c}\text { Tithonian-Neocomian } \\
\text { deltaic sediments }\end{array}$ & $500-2000$ & $\begin{array}{l}\text { Deltaic sedimentation } \\
\text { (late syn-rift) }\end{array}$ \\
\hline & & & Kimmeridgian & & North Exmouth PI & ateau- & Erosion & & & \\
\hline & & 9 & Oxfordian & Ke & Argo Abyssal P & & exceeds & & & \\
\hline-160 & $\frac{5}{5}$ & & Callovian & & & & deposition & & & \\
\hline - & कृ & 믈 & Bathonian & & Jurassit & & Post-rift unconfo & & & \\
\hline & 器 & $\Sigma$ & Bajocian & & $\mathrm{Z}_{2}$ coal & & & & & paralic \\
\hline-180 & $?$ & $\geq$ & $\begin{array}{l}\text { Toarcian } \\
\text { Pliensbachian }\end{array}$ & Je-m & Jurassic $z_{z}$ measures & $2000-3000$ & Rifting. & & & sedimentation \\
\hline - & & 覀 & Sinemurian & & $\mid \begin{array}{ll}\text { Snelf } \\
\text { carbonates }\end{array}$ & & paralic & & & \\
\hline & & & Hettangian & $F V$ & \begin{tabular}{|l|} 
Trachytes, rhyolites, \\
\end{tabular} & & sedimentation & & & \\
\hline-200 & & 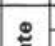 & Rhaetian & $F v$ & lateTriassic siliciclastics & 1500 & & Middle and Late & & \\
\hline & $\frac{0}{\omega}$ & త & Carnian & & and limestone & & & Triassic & $1500-2500$ & \\
\hline-220 & $\ddot{\leftrightarrow}$ & $\frac{2}{5}$ & Ladinian & R & Middle Triassic paralic & $1000+$ & & $\begin{array}{l}\text { muvio-dentalc } \\
\text { sediments }\end{array}$ & & \\
\hline & $\bar{x}$ & $\begin{array}{l}2 \\
2\end{array}$ & Anisian & & \begin{tabular}{|l|} 
detrital seoiments \\
\end{tabular} & & Intracratonic basin & & & Intracratonic basin \\
\hline-240 & & แึ๊ & Scythian & & $?$ & $?$ & & $\begin{array}{c}\text { Early Triassic } \\
\text { shallow marine shale }\end{array}$ & $?$ & \\
\hline
\end{tabular}

Figure 2. Simplified stratigraphy of the Exmouth Plateau. The "North Exmouth Plateau" is north of $18^{\circ} \mathrm{S}$. 


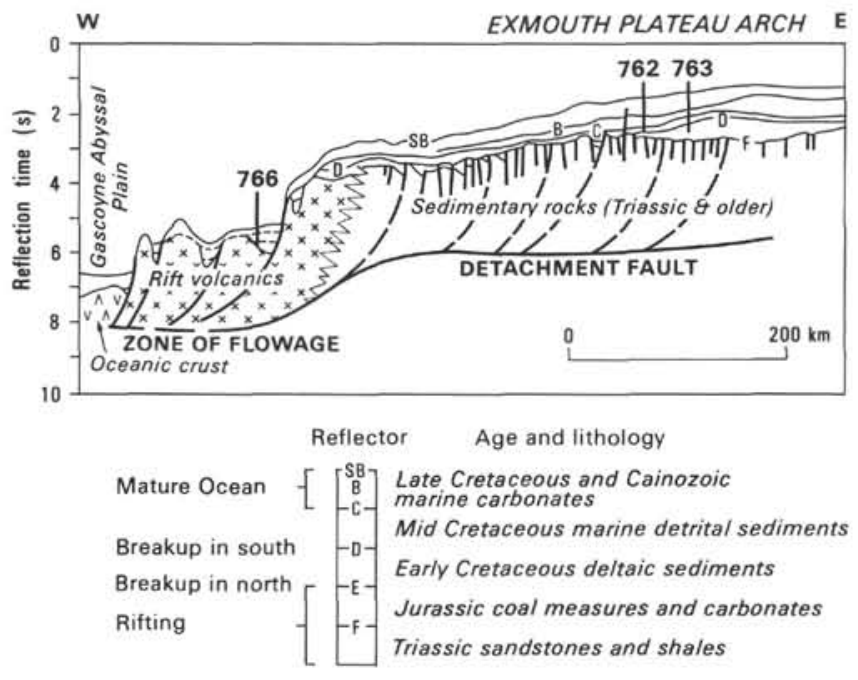

Figure 3. Schematic cross-section, extending westward from the central Exmouth Plateau to Gascoyne Abyssal Plain, linking Sites 762,763 , and 766 (see Fig. 1 for locations). Based on seismic profile BMR 17/68.

(BMR) and Lamont-Doherty Geological Observatory in 1986 has provided vital information on the early history of the Exmouth Plateau (Mutter et al., 1989; Williamson et al., 1990). This study shows that there are near-horizontal reflecting surfaces at mid-crustal depths, which separate rocks with lower velocity (above) from rocks with much higher velocity. No faults are seen to penetrate below these surfaces, which are interpreted to be detachment surfaces between sediments and what Williamson et al. (1990) believe to be an upper plate in the east and an intermediate plate in the west (Fig. 5). The intermediate plate presumably consists of a variety of rocks which were dragged out to the west from beneath the upper plate during a period of crustal stretching in the PermoTriassic (probably Late Permian from evidence in the eastern Carnarvon Basin). This period of stretching (about $40 \%$ ) and thinning gave rise to rapid subsidence in the Triassic, leaving space for $4 \mathrm{~km}$ or more of Triassic fluviodeltaic sediments to be deposited and probably causing magmatic underplating. A second period of stretching (about $5 \%$ ) in the latest Triassic to Late Jurassic caused the characteristic normal faults in the Triassic and Jurassic strata of the plateau, which terminate downward at the detachment surface (Williamson et al., 1990).

It is highly probable that Lower Triassic rocks, equivalent to the marine Locker Shale of the Carnarvon Basin beneath the Northwest Shelf, exist toward the base of the Exmouth Plateau section. However, the oldest rocks recovered from the plateau are Carnian sandstones and siltstones in the Upper Triassic Mungaroo Formation, which was laid down across the region from the south as a fluviodeltaic blanket. Triassic fluviodeltaic deposition persisted into the Rhaetian, but shelf carbonates occur sporadically throughout the Upper Triassic, and are particularly well developed on the distal northern margin of the delta in the Rhaetian (Table 3 and von Rad et al., 1990).

Deposition of coarse-grained Jurassic shelf carbonates persisted into the Early and possibly Middle Jurassic (Quilty, 1990). Shallow-marine and floodplain Jurassic mudstones and sandstones fill depocenters in the northern and eastern plateau and on the Northwest Shelf, but there are only condensed sections of marly sediments on the central plateau. The second phase of stretching and block-faulting culminated in the Callovian to Oxfordian, and there were associated uplift and erosion in some areas, so Upper Jurassic rocks are not common on the plateau. This period of tectonism finally led to breakup of the northern margin and formation of the Argo Abyssal Plain in the Late Jurassic to Berriasian. There are virtually no faults extending above the Jurassic on the plateau.

Another major phase of sedimentation occurred in the Berriasian (earliest Cretaceous), and thick sandstones and mudstones of the Barrow delta prograded northward across the southern plateau and adjacent Northwest Shelf. After the late Valanginian breakup that formed the Gascoyne and Cuvier abyssal plains, the plateau was far from detrital sources, and detrital input declined during the Cretaceous. The plateau sank steadily throughout the Cretaceous as a result of its linkage to the thermally subsiding abyssal plains. Cretaceous and Cenozoic sequences are generally thin (Fig. 2). Aptian and Albian mudstones give way to marls and chalks in the middle Cretaceous and finally to chalks in the Late Cretaceous. Oozes, chalks, and marls characterize Cenozoic strata.

\section{Petroleum Exploration}

In the mid-1970s the Exmouth Plateau was regarded as having considerable petroleum potential. Reconnaissance reflection seismic surveys shot in the 1970 s revealed the presence of large fault-bounded structures (Willcox and Exon, 1976; Exon and Willcox, 1978; Wright and Wheatley, 1979), and the close proximity of major hydrocarbon accumulations beneath the Northwest Shelf and at Barrow Island in the Carnarvon Basin encouraged optimism. Five exploration permits divided up the plateau in 1977, many seismic data were recorded, and 16 exploration wells were drilled in the central and southern areas (Fig. 1). Several noncommercial gas shows were encountered, as well as the Scarborough gas discovery that has been retained by EssoBHP.

Early exploration concepts involved generation of oil from Upper Jurassic and Neocomian shales in the Kangaroo Syncline, and subsequent migration into the Triassic/Jurassic tilted fault blocks on the broad arch of the Exmouth Plateau, or generation from marine Triassic rocks within the fault blocks. The lack of liquid hydrocarbons in the exploration wells was attributed to unfavorable source rocks, unsuitable burial history, and a low paleo-thermal gradient. In three wells (Phillips Saturn No. 1, Jupiter No. 1, and Mercury No. 1) on the central plateau, Upper Triassic, Jurassic, and Cretaceous sections were found to be immature and incapable of generating hydrocarbons. Most hydrocarbons so far encountered on the Exmouth Plateau are thought to have originated from deep (5 $\mathrm{km}$ or more), overmature gas source rocks, probably Lower Triassic and Permian shales, by tapping of source beds along faults bounding the tilted block structures, enabling the gas to migrate upward (Barber, 1982, 1988).

The failure to find oil in the major Exmouth Plateau structures has resulted in the dropping of all except part of one permit and the cessation of petroleum exploration on the plateau. Future petroleum exploration interest would appear to depend largely on demonstrating a marine oil-prone source at mature depths, either in Jurassic graben-fill sediments in the Kangaroo Syncline or local grabens, or in Triassic and Permian pre-rift sediments on the western or northern margins of the plateau, along with suitably located trapping structures.

The exploration drilling showed that shelf carbonates of Late Triassic and Jurassic age were common on the Exmouth Plateau (Table 3). Barber (1988) stated that in the central plateau, a shallow sea transgressed over the fluviodeltaic sequence of the Mungaroo Formation during late Rhaetian to Hettangian time, depositing an interbedded sequence of cal- 


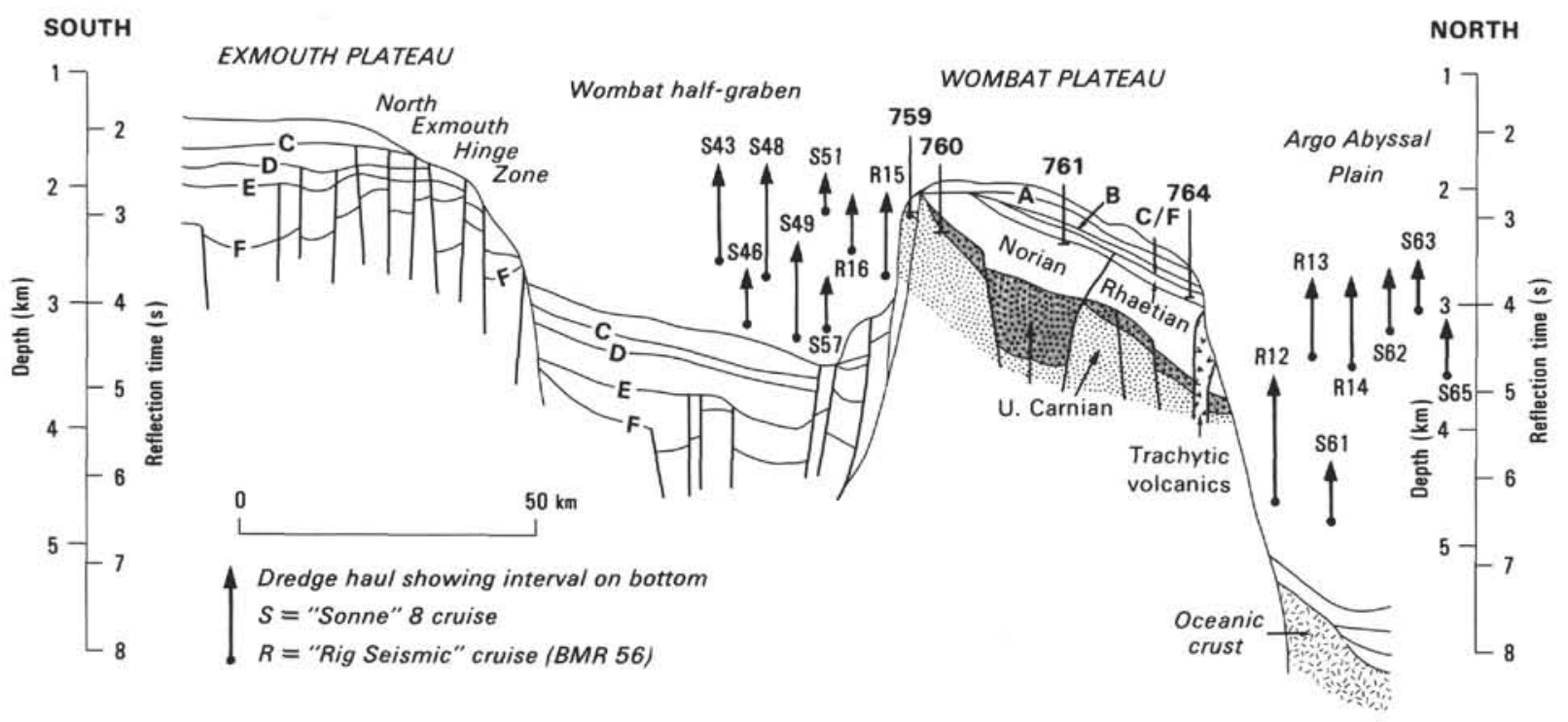

South of Wombat Plateau

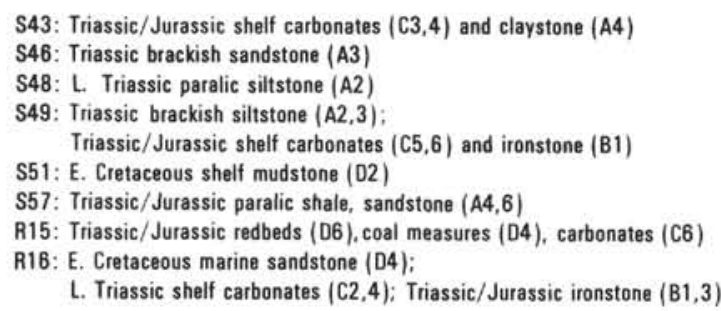

North of Wombat Plateau

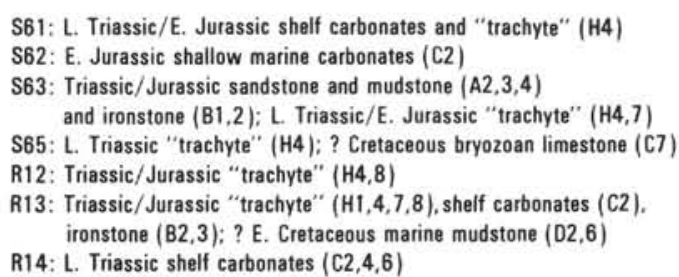

Figure 4. Cross-section, based on seismic profile BMR 56/13, extending northward from the northern Exmouth Plateau across Wombat Plateau. Shows Sites 759, 760, 761, and 764 (locations in Fig. 1), projected locations of dredge hauls from Sonne SO-8 and Rig Seismic BMR-56 cruises, and summaries of the Mesozoic rocks dredged. After von Rad et al. (1990).

careous sandstone, siltstone and occasional limestone. The total thickness of this sequence is about $100-300 \mathrm{~m}$. Farther shoreward to the southeast, at the intersection of the prograding fluviodeltaic regime with the marine transgressive front, a north-northeast-trending, beach-barrier bar and back-lagoonal complex developed. As deltaic input diminished, carbonate deposition predominated, and the base of the Jurassic Dingo Claystone is largely carbonate.

Williamson et al. (1989) reported the discovery of a Triassic reef drilled during Leg 122 at Site 764 on the Wombat Plateau, the first found in Australia, and put together a Late Triassic paleogeographic map (Fig. 6), which suggested that such reefs could provide a new exploration play. The recently acquired seismic profile BMR 95-22 across Site 764 (Fig. 7) gives a good idea of the character of Wombat Plateau reefs, which appear to consist of a barrier in the north and patch reefs further south.

\section{Seismic and Dredging Studies}

Key studies of the northern Exmouth Plateau area were conducted by:

1. BMR, from 1974 to 1978 , using regional seismic data and well ties (Willcox and Exon, 1976; Exon and Willcox, 1978, 1980).

2. Bundesanstalt für Geowissenschaften und Rohstoffe (BGR) and BMR, from 1979 to 1983, using new dredge and core information gathered by the Sonne to upgrade the earlier interpretations (von Stackelberg et al., 1980; Exon et al., 1982; von Rad and Exon, 1983).
3. BMR, from 1986 to 1990 , using new dredge and multichannel seismic data gathered by Rig Seismic in 1986 (Exon and Williamson, 1988; von Rad et al., 1990).

All this work showed that, adjacent to the northern margin of the Exmouth Plateau, there is a complex of horsts and grabens produced by vertical movements along northeast- and east-striking faults (e.g., fig. 4 in von Rad et al., this volume). Displacements on individual faults of either trend exceed 1000 $\mathrm{m}$ in places. Closely-spaced faults have caused a total displacement of the order of $2500 \mathrm{~m}$ down the lower continental slope. Gravity modelling indicates that the crust thins abruptly under the lower continental slope.

Several small subplateaus in water depths of 1600-2300 m coincide with the horst blocks and were once part of the Exmouth Plateau. The largest, the Wombat Plateau (Fig. 1), covers an area of about $3500 \mathrm{~km}^{2}$. Identification of seismic horizons in the northern area is impeded by lack of continuity between the subplateaus across the grabens that separate them, and between the subplateaus and the Exmouth Plateau proper.

In general, the northern margin of the plateau is downwarped along the extensively faulted North Exmouth Hinge Zone (Fig. 4), which is made up of numerous blocksdownfaulted northward or northwestward into a series of halfgrabens. The subplateaus which separate the half-grabens from the Argo Abyssal Plain are largely composed of westdipping Jurassic and Triassic strata, beneath nearly horizontal Cretaceous and Cenozoic strata, and buttressed against collapse by igneous intrusions along their northern edges. 

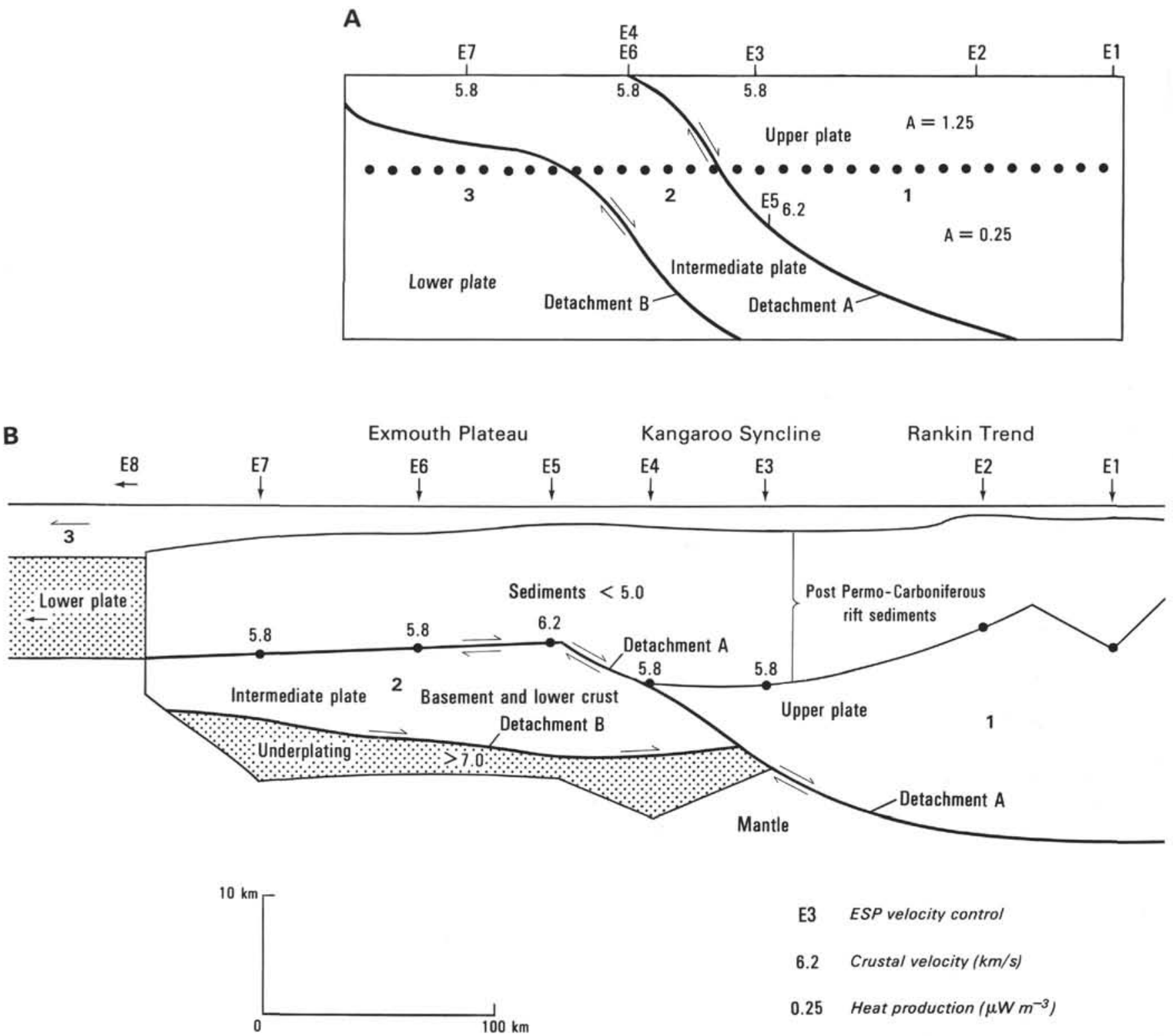

Figure 5. A. Paleozoic configuration of east-west Exmouth Plateau section showing upper, intermediate, and lower crustal plates prior to Permian rifting. Shown are the velocity control on the present-day top of basement and the thermal properties of the primary crust. $1=$ upper plate, 2 = intermediate plate, and $3=$ lower plate. The dotted line separates levels with different thermal properties. Their final configuration is shown in (B). B. Generalized depth section along the Exmouth seismic transect, showing the present-day distribution of upper, intermediate, and lower plate segments, which resulted from the basement and lower crustal configuration established by Permian rifting. Plate 3 was ultimately removed by Neocomian breakup and seafloor spreading. Permian, Mesozoic, and Cenozoic sedimentary cover is shown, along with velocity control. After Williamson et al. (1990).

On Emu and Echidna spurs (Figs. 1 and 8), west of the Swan Canyon, Mesozoic strata lie beneath a wave-cut platform upon which Cenozoic (and minor Cretaceous) carbonates have been deposited. This area is thought to have been structurally high in the Late Jurassic. The Sonne results show that a thick, dipping Jurassic sequence underlies the almost planar post-rift unconformity. This sequence consists largely of Lower and Middle Jurassic shelf carbonates and coal measures. Details of the rock types are given in von Stackelberg et al. (1980), von Rad and Exon (1983), and von Rad et al. (1990), and brief summaries are provided in Figure 8.
In the Wombat Plateau region (Figs. 1 and 4), dredging showed that the same main unconformity is underlain by thick Upper Triassic detrital sediments, Triassic to Jurassic shelf carbonates, and Triassic/Jurassic volcanics. A thin, largely Cenozoic sequence rests on the unconformity. These rocks have been described in detail by von Stackelberg et al. (1980), von Rad and Exon (1983), and von Rad et al. (1990), and the results are briefly summarized in Figure 4.

\section{Objectives}

Legs 122 and 123 drilled two complete transects from the continental margin to old ocean basins across the Exmouth 
Table 3. Upper Triassic to Lower Jurassic carbonates in drill holes on the Exmouth Plateau.

\begin{tabular}{|c|c|c|c|}
\hline Well & Location & Description & Carbonate thickness (m) \\
\hline ODP Site 764 & Northeast Wombat & Rhaetian shelf limestone & 230 \\
\hline ODP Site 761 & East Wombat & Late Norian to Rhaetian shelf limestone & 140 \\
\hline ODP Site 760 & Southeast Wombat & $\begin{array}{l}\text { Thin late Carnian to Norian limestones in } \\
\text { deltaic sediments }\end{array}$ & 30 \\
\hline ODP Site 759 & Southeast Wombat & $\begin{array}{l}\text { Norian shelf limestone and thin middle Carnian } \\
\text { limestones in deltaic sediments }\end{array}$ & 45 \\
\hline Hudbay Gandara & Northeast Exmouth & $\begin{array}{l}\text { Hettangian-Pliensbachian marl, calcilutite, } \\
\text { oolitic limestone }\end{array}$ & 15 \\
\hline Hudbay Brigadier & Northeast Exmouth & $\begin{array}{l}\text { Hettangian-Pliensbachian marl, calcilutite, } \\
\text { oolitic limestone }\end{array}$ & 184 \\
\hline Woodside Delambre & Northeast Exmouth & ?Hettangian-Pliensbachian limestone & thin \\
\hline Phillips Saturn & Central Exmouth & Hettangian shelf limestone & 40 \\
\hline Phillips Mercury & Central Exmouth & $\begin{array}{l}\text { Hettangian shelf limestone (minor } \\
\text { Norian-Rhaetian limestone) }\end{array}$ & 70 \\
\hline Phillips Jupiter & Central Exmouth & $\begin{array}{l}\text { Rhaetian shelf limestone (minor } \\
\text { Norian-Rhaetian limestone) }\end{array}$ & 23 \\
\hline Esso Eendracht & Western Exmouth & Rhaetian marl & 47 \\
\hline Esso Vinck & Western Exmouth & Rhaetian marl, shelf limestone & 45 \\
\hline Esso Investigator & Southern Exmouth & Rhaetian marl, Early and Middle Jurassic marl & 109 \\
\hline Esso Sirius & Southern Exmouth & Rhaetian marl, Liassic marl & 111 \\
\hline
\end{tabular}

Plateau, one to the Argo Abyssal Plain and the other to the Gascoyne Abyssal Plain (Fig. 1). All except the two abyssal plain sites-765 and 766-were drilled on Leg 122. The two transects served the following broad objectives:

1. To understand the structural, paleoenvironmental, and magmatic development of this sediment-starved margin, one of the oldest margins bordering the Indian Ocean, from the syn-rift stage to the juvenile stage, and finally the mature post-breakup stage.

2. To improve Late Triassic to Cretaceous chronostratigraphy and the Mesozoic time scale.

3. To document the temporal and spatial distribution of the Mesozoic and Cenozoic depositional sequences in order to separate the effects of vertical tectonics (basin subsidence and uplift), sediment supply, and sea-level changes, thus testing sequence-stratigraphic and eustatic models and other hypotheses of rhythmic sedimentation.

\section{GENERAL RESULTS OF ODP DRILLING}

This brief summary is expanded considerably in the two general synthesis papers in this volume: on the central Exmouth Plateau by Haq et al. (chapter 47) and on the Wombat Plateau by von Rad et al. (chapter 46). Table 1 gives the location, water depth, total penetration, and oldest sediment recovered for all the ODP sites.

\section{Central Exmouth Plateau}

The two ODP sites on the central Exmouth Plateau-762 and 763-were located on the western flank of the culmination of the plateau in water $1360-1370 \mathrm{~m}$ deep (Fig. 1). Because of fears about possible gas blowouts, the JOIDES Safety and Pollution Prevention Panel requested that they be located close to two commercial wells-Esso Eendracht No. 1 and Esso Vinck No. 1. In this way the gas logs of the commercial wells could be used to predict any dangers, and the holes could be terminated in good time. Gas values were measured continuously on the ODP cores to ensure that there were no unexpected variations and the holes were terminated well above known gas sands low in the Cretaceous sequence.

The two ODP sites were located on Leg 122 single-channel seismic line 6 (Fig. 9). This line illustrates the marked thinning of the Lower Cretaceous sequence northward, and the overall thickening of the Upper Cretaceous and Cenozoic sequences in the same direction. From the southern site (763) we recovered a fairly complete middle Berriasian to Campanian section (total sequence $1000 \mathrm{~m}$ ), and from the northern site (762) an almost complete Maestrichtian to Quaternary section (total sequence $650 \mathrm{~m}$ ). The oldest sediments drilled (Fig. 10) were part of a prodelta sequence of the Barrow Group, laid down during a period of tectonic activity immediately before and related to breakup of the plateau's southern margin. Tectonic uplift provided abundant detrital material which was deposited very rapidly in the Berriasian. Sand bodies represent turbidites in a generally clayey prodeltaic sequence.

The Berriasian sequence is capped by a condensed unit of lower Valanginian sandstone, limestone, and claystone, which in turn is capped by a prominent unconformity (the late Valanginian "breakup unconformity"). Thereafter, the plateau sank rapidly, and lower Aptian silty claystone gave way first to Albian to Cenomanian marls, and then to Turonian to upper Campanian chalks. An anoxic event gave rise to thin black shales at the Cenomanian-Turonian boundary. Chalk characterizes the Late Cretaceous and Paleogene, and pelagic carbonate oozes the Neogene.

Figure 10 is a composite diagram from the two ODP sites and Vinck No. 1 well, which relates lithology and age to Northwest Shelf lithostratigraphic nomenclature, environment of deposition, tectonic events, and seismic reflector and sequence nomenclature. It clearly shows the change from the syn-rift, lower Neocomian clastic sedimentation of the Barrow Group to Hauterivian to lower Albian juvenile-ocean claystone sedimentation, to upper Albian to Turonian hemipelagic open-ocean deposition of marl and chalk, and to the post-Turonian open-ocean conditions that resulted in deposition of ooze, chalk, and minor marl. 

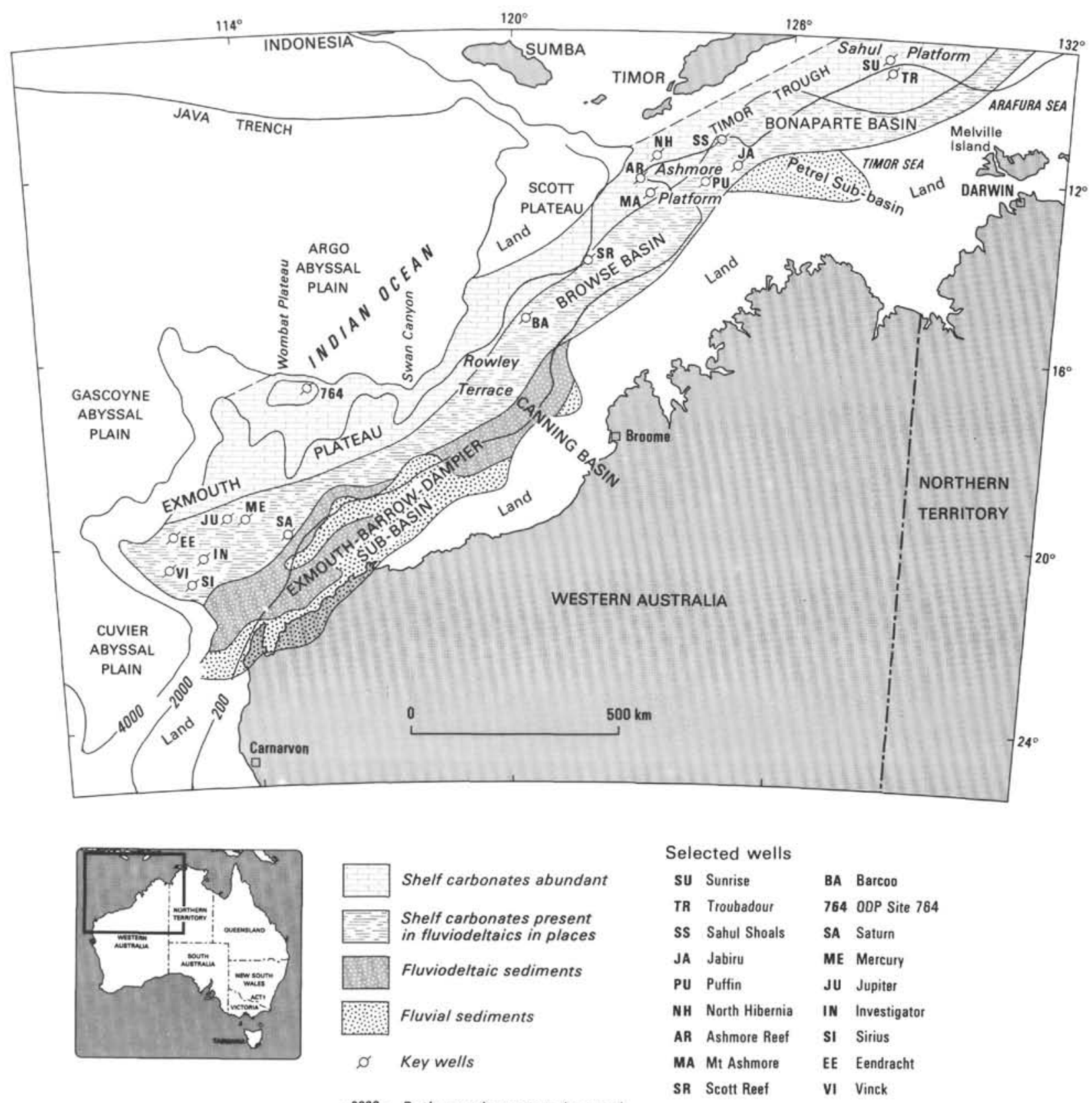

-2000- Bathymetric contour (metres)

Figure 6. Sketch map of Upper Triassic sedimentation on the Northwest Shelf, derived largely from well information. After Williamson et al. (1988), based partly on Bradshaw et al. (1988).

\section{Wombat Plateau}

The four ODP sites on the Wombat Plateau-759, 760, 761, and 764-were drilled on the eastern plateau in water 1970$2700 \mathrm{~m}$ deep (Fig. 1). The four sites were located close to multichannel seismic profile BMR 56-13 (Fig. 11). The profile shows the major, wave-cut, post-rift unconformity between Upper Triassic and Neocomian rocks, with progressively younger Triassic rocks underlying this unconformity northward (Williamson, this volume).

A composite diagram (Fig. 12) making use of Sites 760 , 761 , and 764 shows the thickest sequences of each age in the sites: $700 \mathrm{~m}$ of Upper Triassic, less than $100 \mathrm{~m}$ of Cretaceous, and nearly $200 \mathrm{~m}$ of Cenozoic sediments. It compares lithology and age with depositional environment and tectonic events. The Carnian and Norian rocks are largely deltaic siltstone and mudstone derived from the south, but shallow-marine limestones formed in mud-free locations. Deposition was in environments varying from coastal plain to prodelta. In the Rhaetian, deltaic sediments no longer reached this area, and a variety of shallow water limestonesopen shelf, reefal, and lagoonal-are preserved. There are no Jurassic deposits preserved beneath the post-rift unconformity at the ODP sites on the Wombat Plateau, but above it there is a thin transgressive lower Neocomian sand overlain by a very condensed Cretaceous chalk sequence and a Cenozoic chalk/ooze sequence containing numerous hiatuses. 


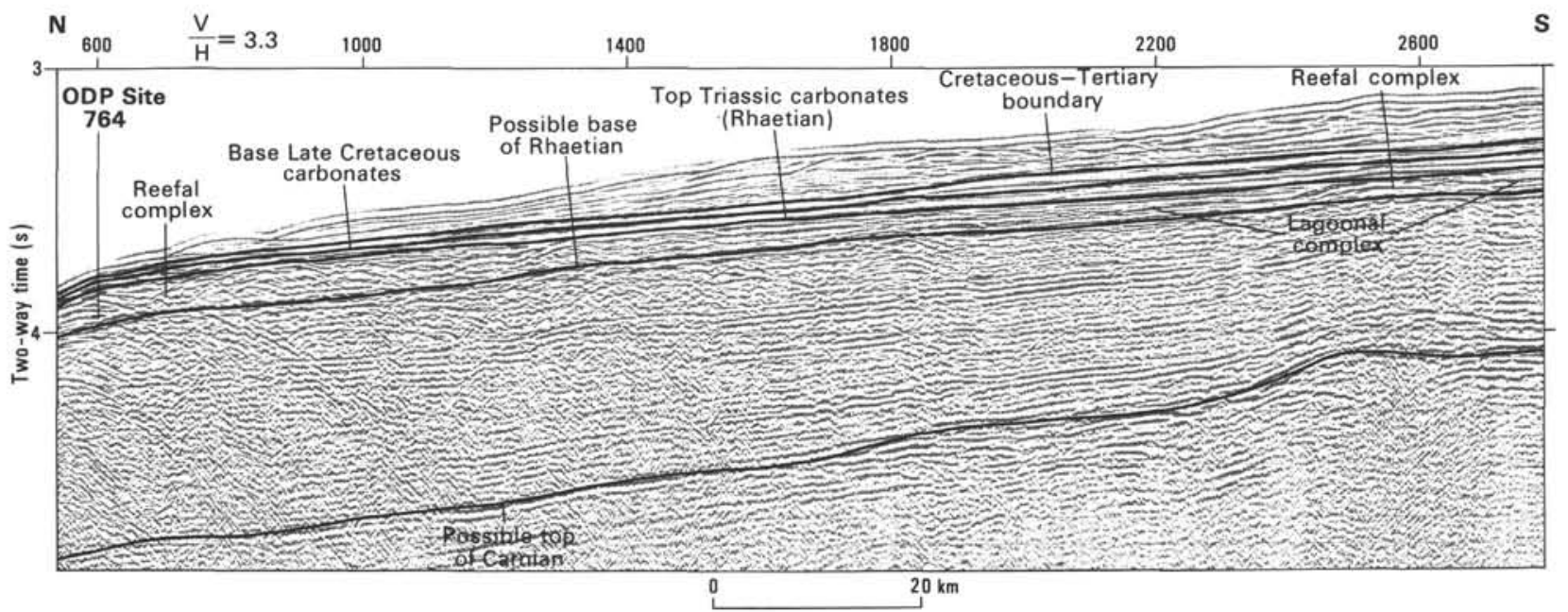

Figure 7. High-resolution, north-south Rig Seismic seismic profile BMR 95/22, extending southward from Site 764 (location in Fig. 1) across the eastern Wombat Plateau, recorded in 1990. Note extent and seismic character of Upper Triassic reefal and lagoonal carbonate rocks.

\section{PALEOGEOGRAPHIC EVOLUTION OF EXMOUTH PLATEAU}

The Triassic history of the continental margins has received little previous attention through scientific deep-sea drilling, although that time interval entailed a unique situation during which only a single continental mass (Pangaea) was surrounded by a single ocean (Panthalassa). In the Jurassic, Pangaea was split by the giant embayment of the equatorial, east-west-trending Tethys Sea into two supercontinents, Laurasia in the north and Gondwana in the south (Fig. 13).

During the Late Jurassic, Gondwana was split into western Gondwana (South America and Africa) and eastern Gondwana (Greater India, Madagascar, Antarctica, and Australia) with a proto-oceanic rift (Weddell Sea-Somali Basin) in between. During the earliest Cretaceous, the eastern Gondwana supercontinent began to break up. Greater India broke apart from the still continuous Australian-Antarctica continent, and other east Gondwanan continental fragments also broke away, such as the south Tibet/Lhasa block, Burma-Malaya, the Timor-Papua New Guinea microplates, Madagascar, and the Apulian plate. All these continental fragments were carried northward from the Australian-Antarctic continent by spreading oceans and collided with and accreted to the Asian continent.

The first documented breakup in the Australian region occurred during the Late Jurassic in the north, about $155 \mathrm{Ma}$, forming the Argo Abyssal Plain between the northern Exmouth Plateau on one side and an unknown lost continental fragment that was presumably later subsumed in Asia (stippled in Fig. 13) on the other. The breakup between the central Exmouth Plateau and Greater India started at least 20 m.y. later than breakup in the north, during the middle Neocomian (about $125 \mathrm{Ma}$ ), and led to the formation of the Gascoyne and Cuvier abyssal plains (Fullerton et al., 1989). At the southwest Australian margin, seafloor spreading started to form the Perth Abyssal Plain at much the same time (Markl, 1978). Rifting between Antarctica and Australia's southern continental margin started with very slow spreading in the Late Cretaceous (Cande and Mutter, 1982; Falvey and Mutter, 1981), whereas fast seafloor spreading began only in the middle Eocene (Weissel and Hayes, 1974; Cande and Mutter, 1982). The demise of Tethys during the Cretaceous to Paleogene compensated for the Late Jurassic to Early Cretaceous opening of the central Atlantic and Indian Oceans (S̨engör, 1985).

Thus, during the Triassic to Jurassic, the Exmouth Plateau was part of a southern Tethyan continental margin, connected with the eastern Gondwana continent and in the vicinity of the Tethys Himalaya-South Tibet depositional area (northeast rim of Greater India) to the west, and of Timor-BurmaThailand-Malaya to the northeast (see also Dewey, 1988; Audley-Charles, 1988). Using all existing data, we have prepared a series of paleogeographic maps of the Exmouth Plateau area, covering the period from the Late Triassic to the Early Cretaceous (Fig. 14). The main data sets for this study are the commercial and ODP wells, but we have also used dredge and geophysical information. Paleolatitudes are derived from various sources including Scotese (1986), Struckmeyer et al. (1990), Ludden, Gradstein, et al. (1990), and especially Ogg et al. (in press). In all the time periods covered by the maps of Figure 14, north generally is at 10 to 11 o'clock (declination $280^{\circ}-330^{\circ}$ ) so that the paleocoastline faced approximately north. According to Ogg et al. (in press) the declination varied fairly regularly, decreasing from about $310^{\circ}$ in the Carnian-Norian to about $280^{\circ}$ in the Oxford-Turonian, and increasing to about $330^{\circ}$ in the Albian.

In the Carnian-Norian (Fig. 14A) the area lay at about $50^{\circ}-55^{\circ} \mathrm{S}$ (declination about $310^{\circ}$ ), with fluviodeltaic siliciclastic sediments of the Mungaroo Formation building northward across it; the Tethyan Ocean probably already existed in the north. The shoreline was roughly where the present shoreline is, and the deltas were supplied with abundant detritus from highlands in the south and east. Late Triassic rifting between Australia and Greater India, along the locus of later breakup on the northwestern margin of the Exmouth Plateau, led to intrusion and extrusion of a suite of volcanic rocks, which formed dry land (Exon and Buffler, this volume). Volcanic clasts in carbonates on the Wombat Plateau also suggest contemporaneous volcanism (von Rad et al., this volume).

The Rhaetian (Fig. 14B) was a period of tectonic quiescence, but the area had moved rapidly northward into subtropical waters at about $25^{\circ}-30^{\circ} \mathrm{S}$. The shoreline had scarcely moved since the Carnian-Norian (Fig. 14A), but deltaic siliciclastic input was restricted to the south. The central plateau was covered in marl, and the northern plateau was covered in shelf carbonates, including reefal and lagoonal deposits (e.g., Fig. 7). 


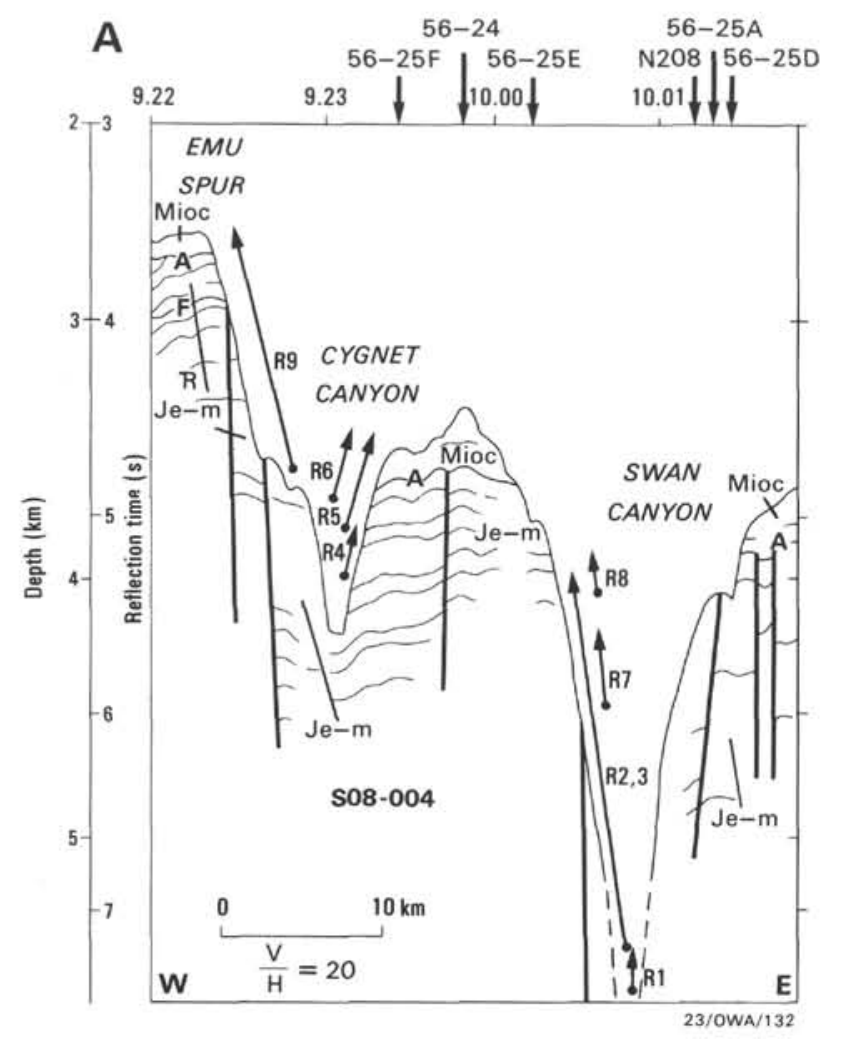

Swan Canyon

R1: ? Jurassic coal measures (A2,3,4); ? Cretaceous marine clay (D3)

R2: Callovian coal measures (A2,3,4); ? Cretaceous marly clay (D2)

R3: ? Jurassic coal measures $(A 2,3,4)$

R7: ? Early Cretaceous marine shale, sandstone $(D 3,4,6)$

R8: ? Jurassic ironstone $(B 1,2,5)$; ? Cretaceous marine claystone, sandstone $(03,4,6)$

Cygnet Canyon

R4: Callovian shelf carbonates (C2,3,4,8); ? Jurassic coal measures (A2) and ironstone $(B 1,2,3) ;$ ? Cretaceous marine claystone (D5)

R5: ? Jurassic coal measures (A2) and ironstone (B3)

R6: ? Jurassic ironstone (B3); Late Aptian and Cenomanian marine mudstone, sandstone, conglomerate $(D 2,4,6)$

R9: ? Oxfordian shelf carbonates $(C 1,3,4)$ : ? Cretaceous marine sandstone, mudstone $(02,4,6,7)$

Figure 8. Line drawing of east-west Sonne seismic profile SO8-004 across Swan and Cygnet canyons about $200 \mathrm{~km}$ east of the Wombat Plateau. Shows projected (A) Sonne SO-8 (S) and (B) Rig Seismic BMR56 (R) dredge hauls and summaries of Mesozoic rocks dredged. Location shown in Figure 1. After von Rad et al. (1990).

In the Hettangian to Sinemurian (Fig. 14C), the paleolatitude was still $26^{\circ}-30^{\circ} \mathrm{S}$ and carbonate deposition continued. Deltaic and shallow-marine sedimentation was concentrated near the shoreline and there was slow and intermittent deposition of shelf marl over most of the plateau. A resurgence of volcanism along the rift zone in the northwest is attested to by rift volcanics dredged from the Wombat Plateau (von Rad and Exon, 1983).

In the Bathonian-Callovian (Fig. 14D), the area had moved to the south again, to a paleolatitude of $35^{\circ}-40^{\circ} \mathrm{S}$, and there was little deposition of carbonates. Major tectonic movements had formed deep, northeasterly-trending, fault-bounded troughs in the east (separated by the horst blocks of the Rankin Platform), in which marine to paralic siliciclastic sediments up to $2000 \mathrm{~m}$ thick were deposited. Much of the area has no preserved sediment and is presumed to have been an exposed erosional area. In the north some shelf limestone persisted (Quilty, 1990).

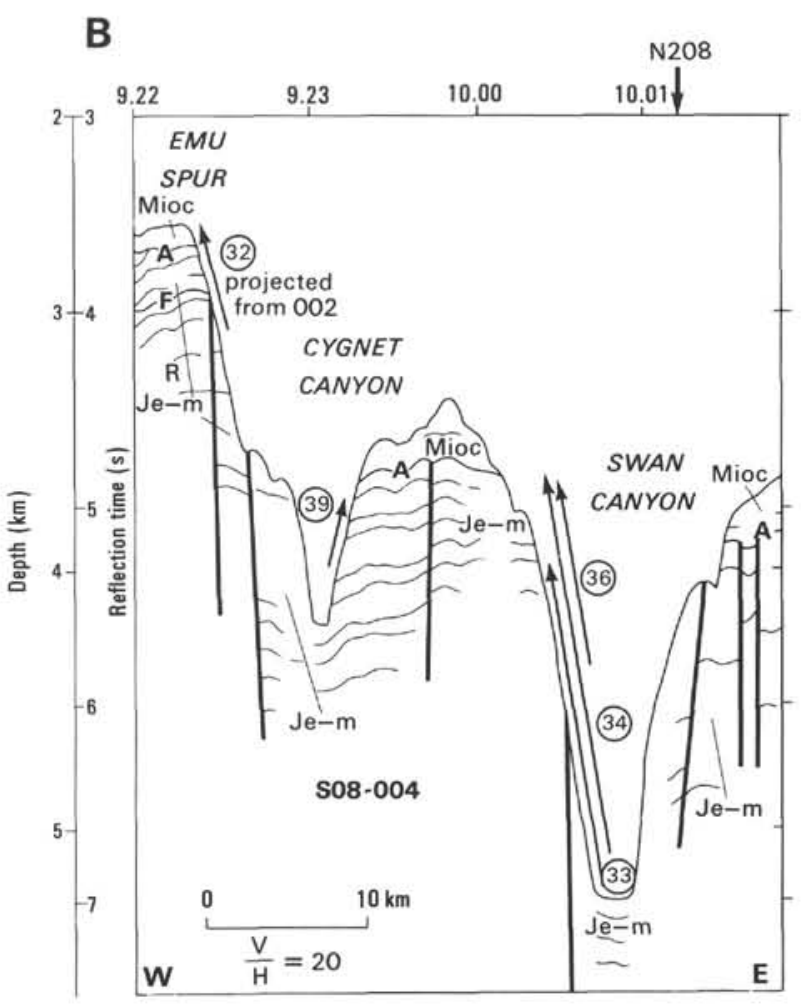

(32) E1 (Middle Miocene chalk): A2,3 (? Jurassic coal measures): $\mathrm{C} 1,2$ (? Jurassic shelf carbonates)

(33) E3,4 (Early Aptian chalk): A2,3 (Middle Jurassic coal measures)

(34) $\mathrm{A} 1-4$ (Middle Jurassic coal measures)

36) E2 (Late Miocene-Early Pliocene chalk); D2 (Late Albian-Early Cenomanian shelf claystone); $A 1-4$ and $B 1,2$ (Middle Jurassic coal measures, some weathered)

(39) $\mathrm{D} 1$ (? Cretaceous/Tertiary claystone); $\mathrm{D} 2$ (Late Albian-Early Cenomanian shelf claystone); B1-4 (? Jurassic terrest/littoral sediments); A4,5 (? Jurassic coal measures); $C 1,2,4,5$ (? Early Jurassic shelf carbonates)
In the late Oxfordian-Kimmeridgian (Fig. 14E), the area was still at $35^{\circ}-40^{\circ} \mathrm{S}$ (declination about $280^{\circ}$ ) and there was no measurable change of paleolatitude from then through into the Albian. This period immediately postdated the formation of the post-rift unconformity that is present everywhere in the Carnarvon Basin (Purcell and Purcell, 1988). There was widespread uplift along the trend of the Rankin Platform and much of the northwestern area was dry land. Marine claystone was deposited southeast of the Rankin Platform, and condensed shelfal series of claystone, marl, and calcilutite were laid down in the southwest and northeast.

There were big changes in depositional patterns in the Berriasian to early Valanginian (Fig. 14F), a period that postdated breakup in the north and immediately predated breakup in the west and south. The area lay at $33^{\circ}-38^{\circ} \mathrm{S}$ (declination about $300^{\circ}$ ). In the south, there was major uplift along the Cape Range Fracture Zone, the shear zone along which the southern margin was to break up (Exon and Buffler, 


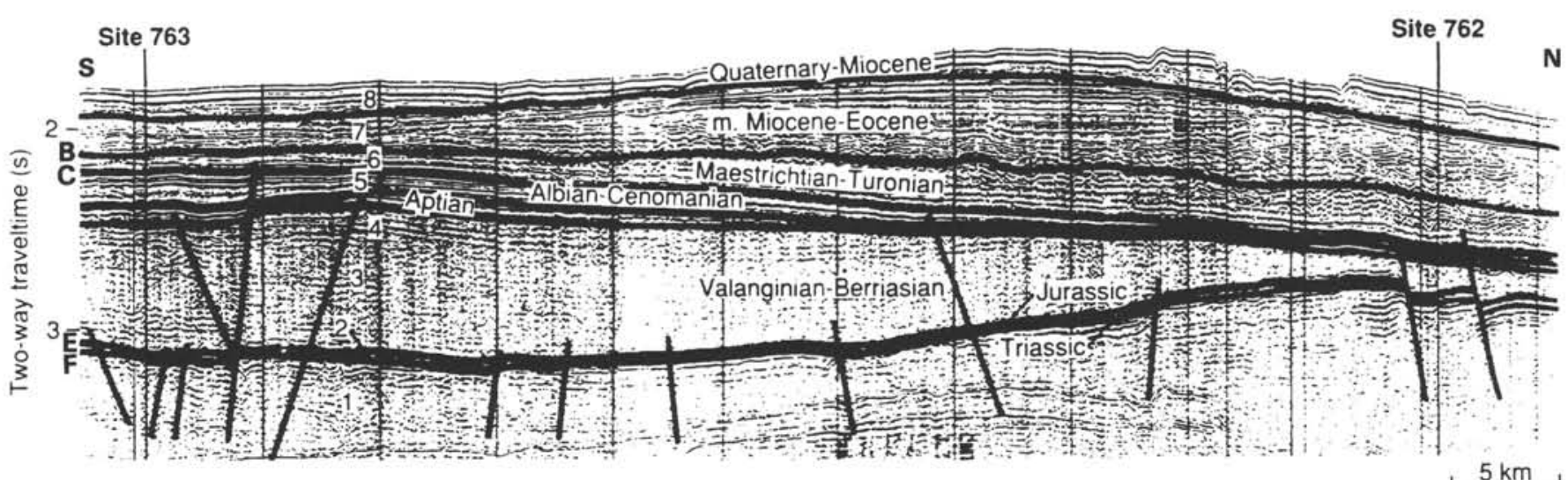

Figure 9. Interpreted north-south, single-channel seismic profile ODP 122-6, extending across Sites 762 and 763 (location in Fig. 1). Note thick deltaic wedge of Valanginian-Berriasian Barrow Group prograding northward.

this volume), and also farther east (Boyd et al., this volume). Deltaic sediments of the Barrow Group, derived from the uplifted areas, flooded northward across the area. Local highs of Triassic-Jurassic volcanics in the south were being eroded. In the north, the breakup that formed the Argo Abyssal Plain and the "proto-Indian Ocean" about a complex of east-westspreading centers during the Late Jurassic to Berriasian, was associated with rapid subsidence of the northern margin of the plateau. There was deposition of a condensed, transgressive, juvenile-ocean sequence (sands, belemnite muds, calcispherenannofossil chalks, and bentonites). Between the northern Exmouth Plateau area and the Barrow delta was an area of nondeposition, and farther south one where thin, shallowmarine to bathyal sediments were laid down. The Joey Rise and Roo Rise (to the northwest) are Neocomian volcanic edifices (epiliths), associated with the formation of oceanic crust, that bound the Argo Abyssal Plain to the west. Widespread ash deposits, produced by the volcanism associated with breakup, are preserved as bentonites in Neocomian sediments in most ODP sites (von Rad and Thurow, this volume).

Following late Valanginian breakup in the west and south, as Greater India moved away to the west, the Exmouth Plateau became a separable entity and not just a part of the northern margin of eastern Gondwana. In the Aptian, the area lay at $35^{\circ}-40^{\circ} \mathrm{S}$ and was bounded to the south by the Cuvier Abyssal Plain and to the west by the Gascoyne Abyssal Plain (Fig. 14G). At the junction between the two, a large volcanic buildup (epilith) had formed (Exon and Buffler, this volume). The main source of terrigenous sediment to the plateau had vanished, but a marine transgression resulted in the shallowmarine (largely outer shelf) Muderong Shale being laid down over most of the plateau. Around the margins of the plateau, bathyal claystone and chalk were deposited.

In the Albian (Fig. $14 \mathrm{H}$ ), the plateau still lay at $35^{\circ}-40^{\circ} \mathrm{S}$ (declination about $325^{\circ}$ ). It was subsiding along with the neighboring abyssal plains. Detrital shallow-marine sediments were laid down in the southeast near the coastline, with a zone of shelf marl beyond them. Hemipelagic to eupelagic claystone, chalk, and calcilutite characterized most of the plateau, and claystone was deposited on the abyssal plains.

Throughout the remainder of the Cretaceous, the plateau continued to sink and the slow rain of pelagic carbonate could not keep up with subsidence. Marl, chalk, and calcilutite characterize Late Cretaceous deposition on the plateau and much of the adjacent Northwest Shelf. Such conditions continued throughout the Cenozoic on the plateau, but once the
Northwest Shelf had drifted northward into tropical waters in the early Miocene, deposition there was characterized by northwesterly-prograding wedges of shelf carbonates. From then on, the plateau was clearly differentiated from the Northwest Shelf by pelagic rather than shelf carbonate deposition.

\section{OVERVIEW OF CONTRIBUTIONS}

In the following section we give a brief outline of the different topics covered by the papers included in this volume. The topics that received most attention by the shipboard and shore-based Leg 122 scientists are: (1) early Mesozoic passive margin evolution and paleoenvironment, (2) Mesozoic biostratigraphy, magnetostratigraphy, and chemostratigraphy, (3) sequence stratigraphy, rift tectonics, and eustatic sea-level fluctuations, and (4) cyclic sedimentation and orbital forcing.

\section{Rift-to-Drift Evolution of a Passive Continental Margin and Early Mesozoic Paleoenvironments}

\section{Physical Properties and Logging Results}

Physical properties of sediments and sedimentary rocks are described, interpreted, and correlated with seismic results in the papers by O'Brien and Manghnani (Site 762) and Lorenzo and Vera (Site 763). Wireline logging results are discussed by Pratson et al. (geochemical logging results from Sites 761, 762, and 764), Golovchenko et al. (sedimentary cycles), and especially by Boyd and Bent (Mesozoic depositional environments). Heat flow levels in Sites 762 and 763 are outlined by Swift et al.

\section{Seismic Stratigraphy and Structural Development}

The seismic stratigraphy of the Upper Triassic reefal section of the Wombat Plateau is discussed by Williamson. The seismic stratigraphy and passive margin evolution of the southern Exmouth Plateau is covered in detail by Boyd et al. Exon and Buffler describe the seismic stratigraphy and passive margin evolution of the western margin of the Exmouth Plateau between Sites 762, 763, and 766.

\section{Carnian-Norian Fluviodeltaic-Dominated Environments}

The siliciclastic sequence is described by Ito et al., and the intercalated carbonate rocks by $\mathrm{Röhl}$ et al.

\section{Rhaetian Carbonate Buildup}

Five papers describe and discuss the conspicuous Rhaetian lagoonal/reefal carbonate sediments of the Wombat Plateau 


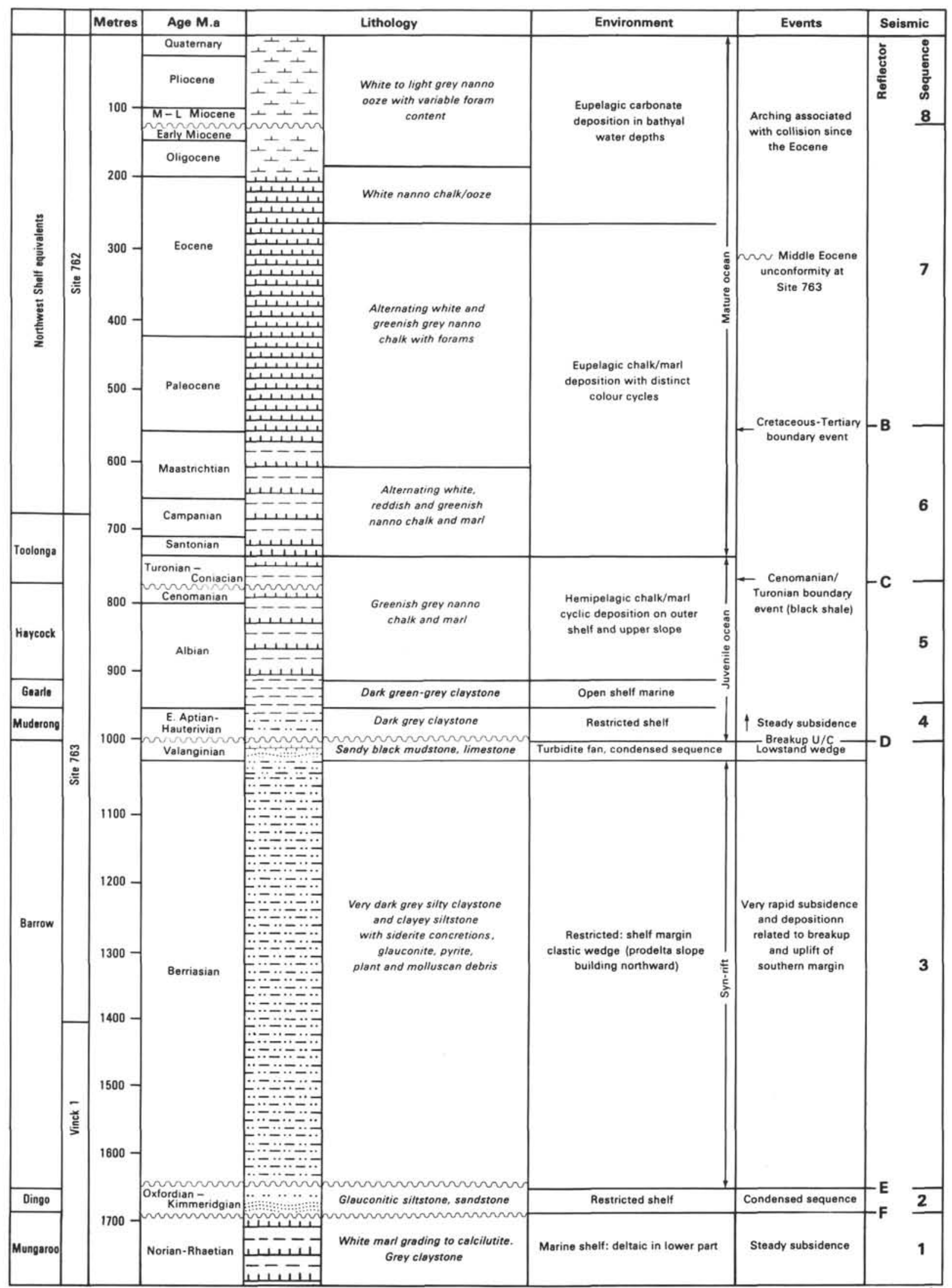

Figure 10. Composite stratigraphic diagram of the central Exmouth Plateau, drawn from Sites 762 and 763, and of Esso Vinck No. 1 well, showing major geological events and correlation to seismic reflectors and sequences. This is constructed to show maximum thicknesses of Cretaceous and Cenozoic strata drilled. 

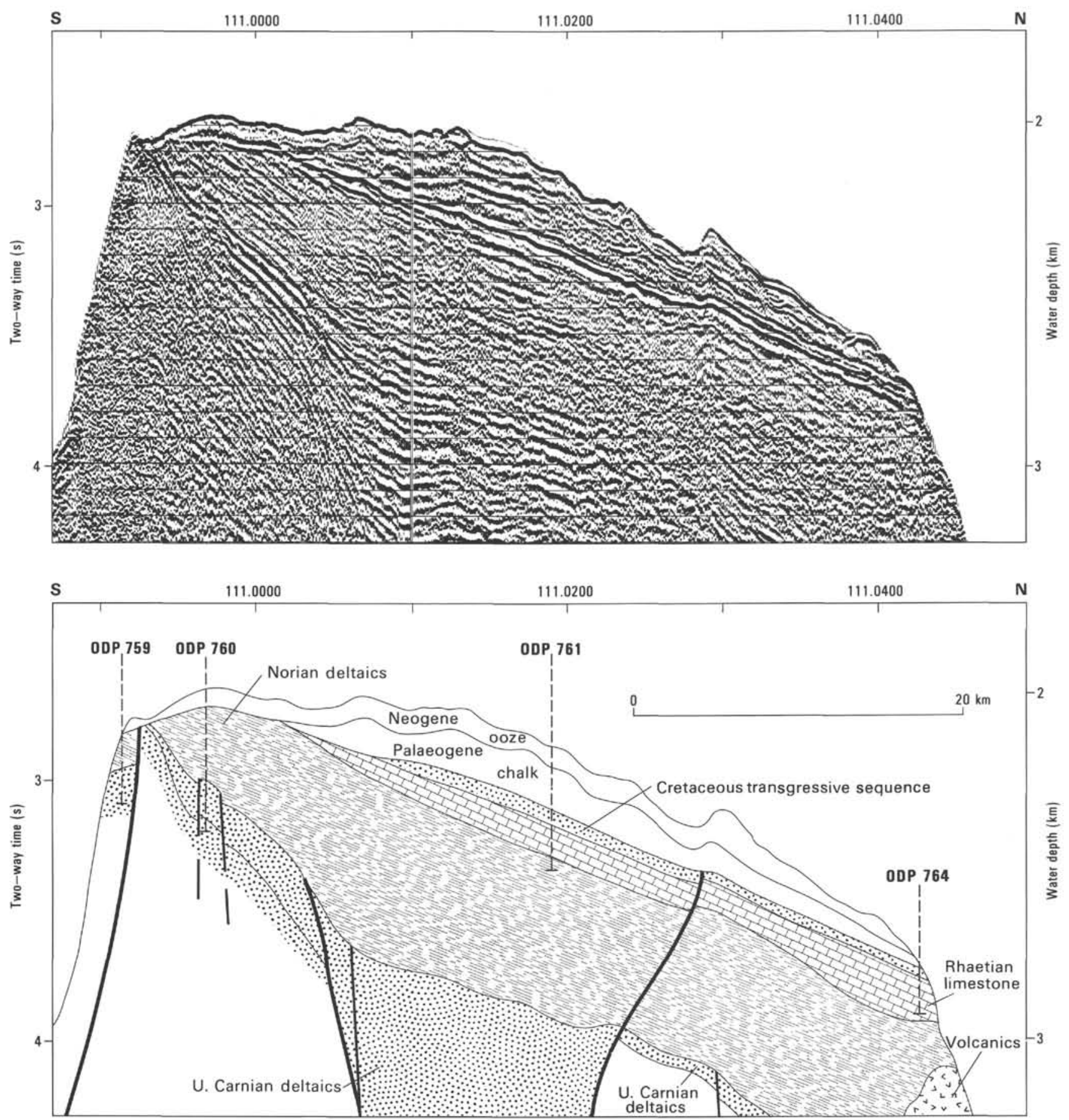

Figure 11. Sites 759, 760, 761, and 764 (location in Fig. 1) projected onto north-south seismic profile BMR 56/13 across the Wombat Plateau. Note major post-rift unconformity between Cretaceous (Neocomian) and Late Triassic sequences.

(Sites 761 and 764): Dumont (paleogeography, sequential evolution, rift tectonics, and eustasism), Röhl et al. (microfacies, paleoenvironment, and carbonate diagenesis), Sarti et al. (coral, algae, sponge taxonomy and reef communities, paleoecology, and paleoenvironment), Sarti (stable isotopic composition of carbonate cements), and Borella et al. (especially correlation with geochemical logs).

\section{Tethyan Relationships}

The early Mesozoic section of the Wombat Plateau is discussed in the context of the Tethyan evolution of northwest Australia and the southeast Asian Tethysides by Görür and Sengör. Comparisons of the Rhaetian section of the Wombat Plateau with the Western Tethys sections of the Northern Calcareous Alps are discussed in Röhl et al. and in Kristan- 


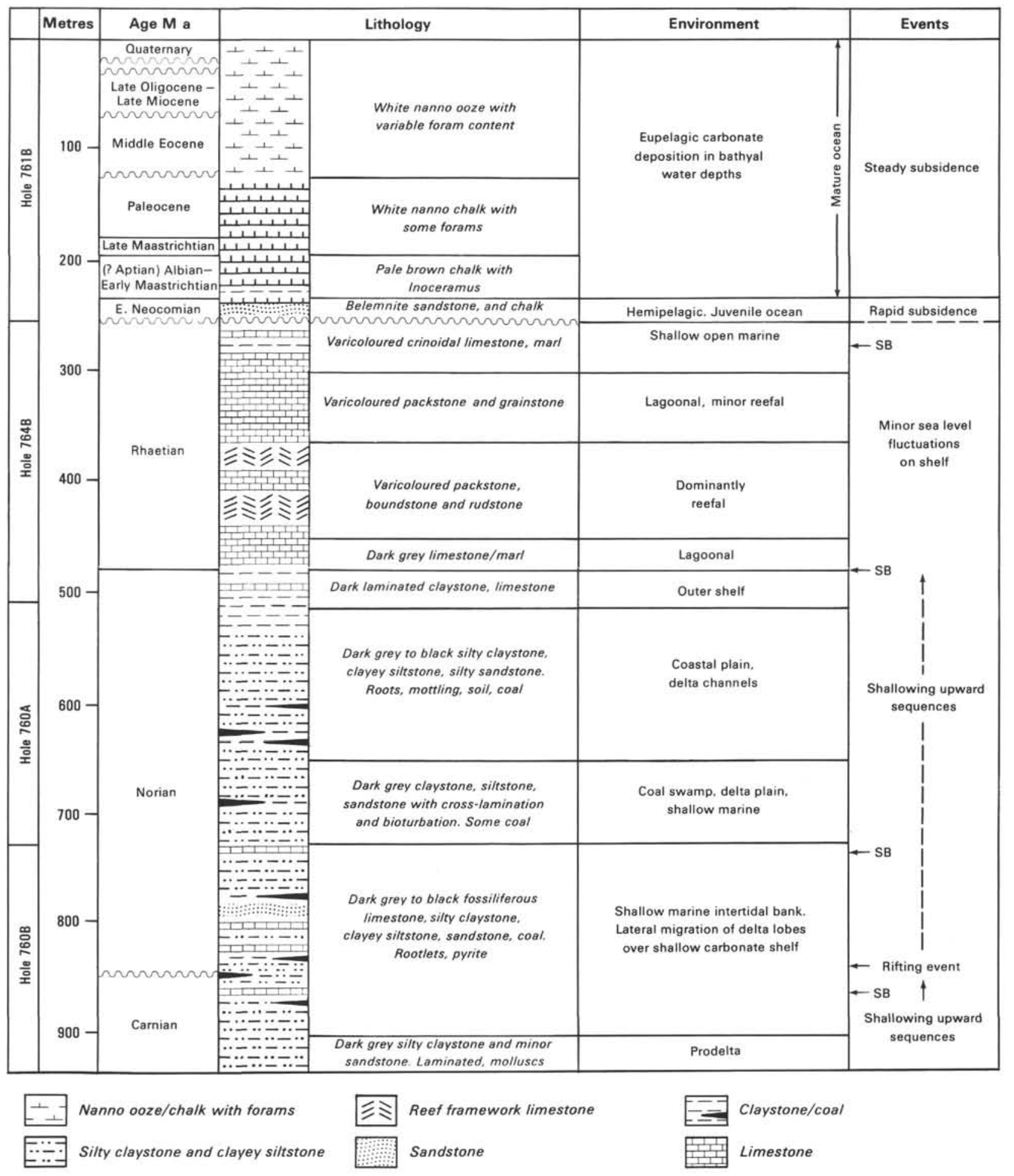

SB Sequence boundary

Figure 12. Composite stratigraphic diagram of the eastern Wombat Plateau, drawn from Sites 760, 761, and 764. This is constructed to show maximum thicknesses of Triassic, Cretaceous, and Cenozoic strata drilled. Note major post-rift unconformity between Neocomian and Upper Triassic sequences. 


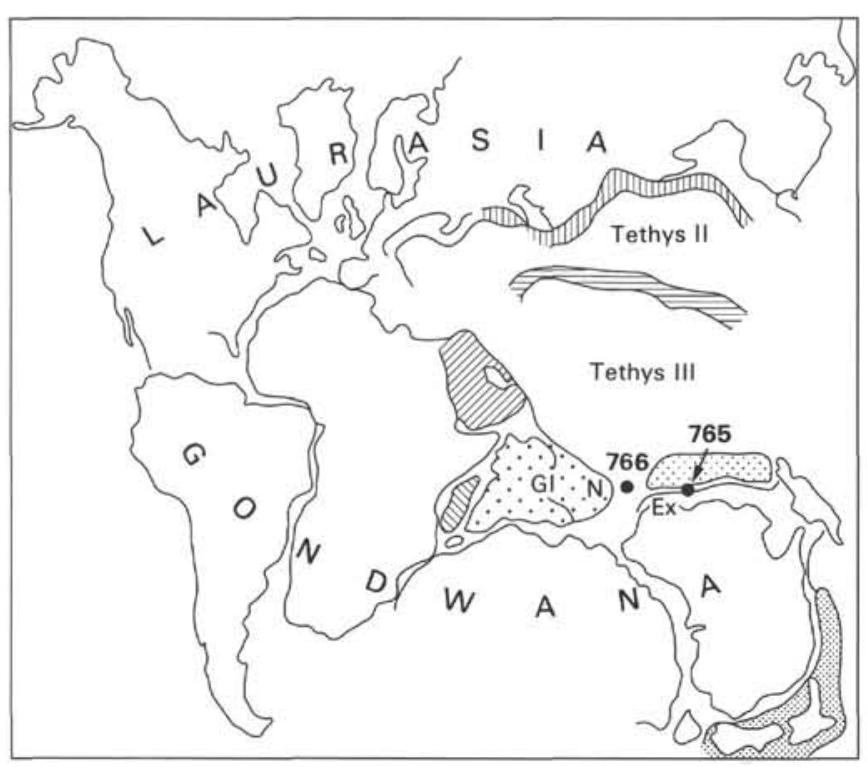

Figure 13. Paleotectonic reconstruction of Tethys in the Late Jurassic, showing Sites 765 and 766. GI $=$ Greater India, $\mathrm{N}=$ Nepal, $\mathrm{Ex}=$ Exmouth Plateau. After von Rad et al. (1989), modified from Dewey (1988).

Tollmann and Gramann. Dumont brings comparisons with the Ligurian Tethys of the Western Alps.

\section{Berriasian-Lower Valanginian Delta Facies}

Berriasian-lower Valanginian delta facies (Barrow Group, Sites 762 and 763) are discussed by three papers: Boyd et al. (seismic stratigraphy and interpretation), Exon et al. (chapter 12: sedimentology), and Odin et al. (glauconite $\mathrm{K} / \mathrm{Ar}$ dating).

\section{Early Cretaceous Juvenile and Late Cretaceous Mature Ocean Development}

The condensed Berriasian belemnite-bearing sand and calcisphere chalk of the Wombat Plateau is described and interpreted by Bralower (stable isotopes) and Keupp (calcisphere biostratigraphy). Von Rad and Thurow describe Neocomian bentonitic clays in Leg 122 and 123 sediments that indicate an important phase of post-breakup volcanism. Exon et al. (chapter 12: sedimentology of Sites 762 and 763) describe the Cretaceous evolution of the central Exmouth Plateau from juvenile to mature stages.

\section{Bio-magneto-chemostratigraphy}

\section{Triassic}

Galbrun (chapter 41) covers the late Carnian to early Rhaetian magnetostratigraphy. The following papers describe the Late Triassic biostratigraphy and paleoenvironments: Brenner (chapter 23: spores, pollen, acritarchs, freshwater algae, and dinoflagellates), Bralower et al. (taxonomy and evolutionary lineages of the oldest calcareous nannofossils ever discovered by DSDP/ODP), Zaninetti et al. (NorianRhaetian foraminifers in Sites 761 and 764), Kristan-Tollmann and Gramann (foraminifers, echinoderms and ostracodes in rocks dredged from the northern Exmouth Plateau), Dépêche and Crasquin-Soleau (ostracodes), and Droser and O'Connell (trace fossils).

\section{Cretaceous}

Brenner (chapter 31) discusses Lower Cretaceous palynomorphs (especially dinoflagellate cysts) and compares them with Australian floras; Bralower and Siesser describe the nannofossil biostratigraphy of Sites 761-764. The Upper Cretaceous planktonic foraminifers are covered by Wonders, and the Lower Cretaceous benthic foraminifers (Sites 762/763) by Jones and Wonders. Other topics include Early Cretaceous calcispheres (Keupp), ostracodes (Damotte), and belemnites (isotopes: Bralower; taxonomy: Mutterlose, in press). The magnetostratigraphy of the Late Cretaceous to Eocene (subchrons C34-C17) is dealt with by Galbrun (chapter 42).

\section{Cenozoic}

Tang covers the Neogene sedimentary paleomagnetism in Sites 762 and 763 (subchrons C5-C1), Siesser and Bralower the calcareous nannoplankton biostratigraphy, and Siesser et al. (chapter 38) the Braarudosphaera-rich Oligocene to lower Miocene sediments at Sites 762 and 763. The planktonic foraminifers are described by Zachariasse (Neogene, Sites 761 and 762), and the ostracodes by Guernet and Galbrun. An important discovery is the expanded Paleocene (-Eocene) section of Site 761 (radiolarian biostratigraphy) by Blome.

\section{Sequence Stratigraphy: Tectonic and Eustatic Control}

Important objectives of Leg 122 were the study of the sequence stratigraphy and the tectonic and eustatic control of passive margin sedimentation. These topics are covered in detail by three papers for the Triassic of the Wombat Plateau sites (Dumont; Röhl et al.; and the synthesis by von Rad et al.). The Early Cretaceous sequence stratigraphy of the southern Exmouth Plateau sites is discussed by Boyd et al. and by Haq et al. in the synthesis chapter.

\section{Geochemistry of Organic Matter, Inorganic Deposits, and Pore Water}

There are four papers on organic geochemistry: Snowdon and Meyers on source and maturity of organic matter; Meyers and Snowdon on the geolipid and isotope biomarkers; Rullkötter et al. on organic geochemistry and petrography; and Meyers and Simoneit on the organic geochemistry of the Cretaceous/Tertiary $(\mathrm{K} / \mathrm{T})$ boundary at Site 761 . De Carlo describes the geochemistry of interstitial waters and associated sediments, and De Carlo and Exon discuss the geochemistry of Fe-Mn deposits on Wombat Plateau. X-ray differentiation data are presented by Wilkens et al.

\section{Cyclicity in Sediments: Orbital Forcing and Other Causes}

Cyclic sediments were recovered especially in the Norian (coal cyclothems), in the Rhaetian (reefal to lagoonal and regressive subtidal to supratidal Lofer-type cycles; Röhl et al., Sarti et al.), in the Aptian/Albian (?Milankovitch cycles), and in the Upper Cretaceous of Site 762 (Huang et al., 41-Ka and 21-Ka Milankovitch cycles; Golovchenko et al., 413-12395-Ka cycles).

\section{Cretaceous/Tertiary Boundary}

A biostratigraphically complete $\mathrm{K} / \mathrm{T}$ boundary was recovered at Site 761 (nannofossil biostratigraphy by Pospichal and Bralower). Rocchia et al. cover the foraminifers, nannofossils, Ir content, clay mineralogy, and magnetostratigraphy across the $\mathrm{K} / \mathrm{T}$ boundary. Meyers and Simoneit discuss the geochemical record and biotic extinction in comparison with sections in Tunisia and Israel. 

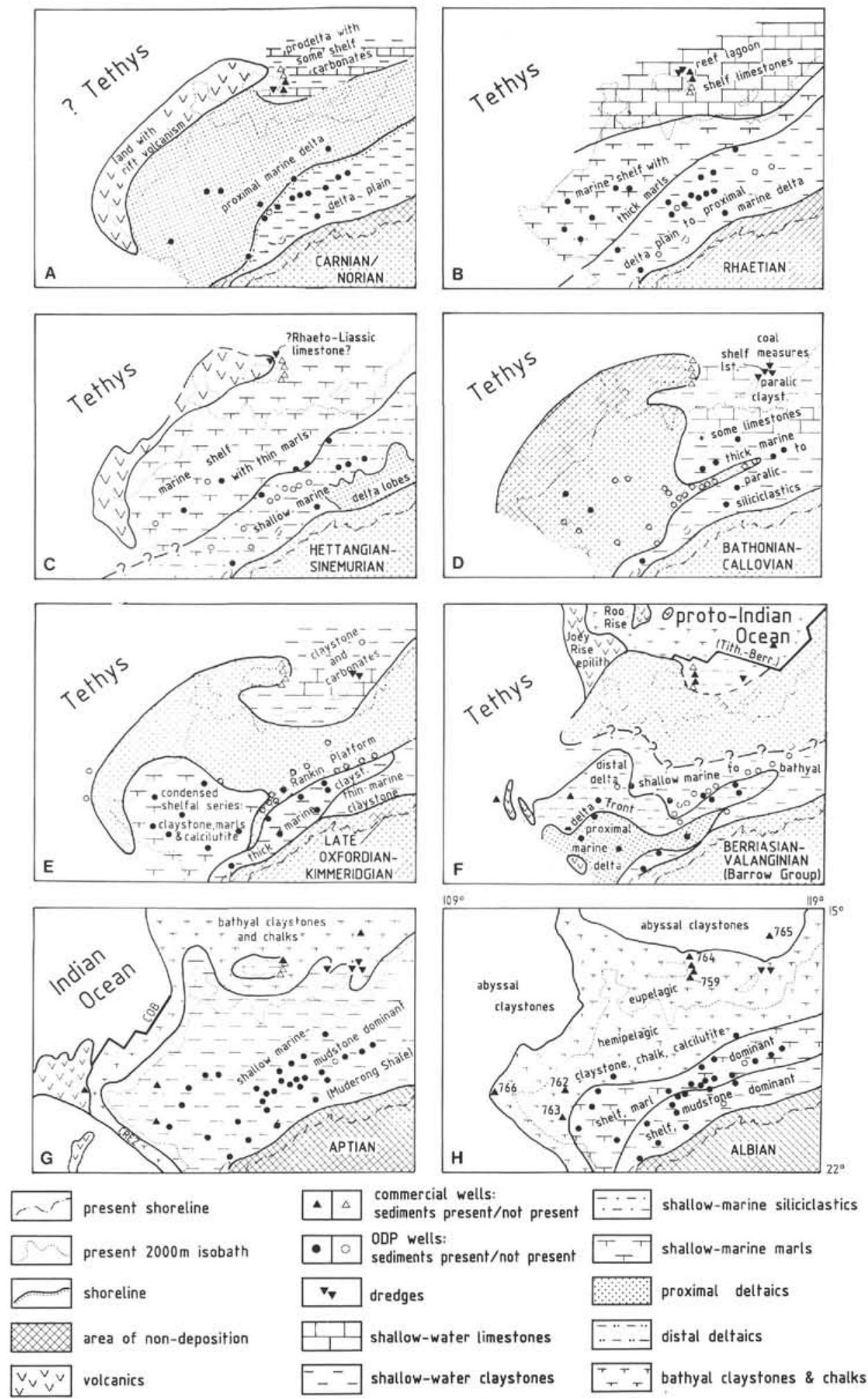

Figure 14. Paleogeographic sketches of the Exmouth Plateau region, drawn from information from ODP sites, commercial oil exploration wells, dredges, and seismic profiles. A. Carnian-Norian (Mungaroo Formation): paleolatitude $50^{\circ}-55^{\circ} \mathrm{S}$. B. Rhaetian: paleolatitude $25^{\circ}-30^{\circ} \mathrm{S}$. C. HettangianSinemurian: paleolatitude $35^{\circ}-40^{\circ} \mathrm{S}$. D. Bathonian-Callovian: paleolatitude $35^{\circ}-40^{\circ} \mathrm{S}$. E. Late Oxfordian-Kimmeridgian: paleolatitude $35^{\circ}-40^{\circ} \mathrm{S}$. F. Berriasian-Valanginian (Barrow Group): paleolatitude $33^{\circ}-38^{\circ} \mathrm{S}$. G. Aptian (Muderong Shale): paleolatitude $35^{\circ}-40^{\circ} \mathrm{S}$. H. Albian (Gearle Siltstone, Haycock Marl): paleolatitude $35^{\circ}-40^{\circ} \mathrm{S}$. Declination was in the range $280^{\circ}-330^{\circ}$ ( $\mathrm{Ogg}$ et al., in press). 


\section{Biostratigraphic Syntheses}

The Triassic biostratigraphy (nannofossils, ostracodes, foraminifers, and palynomorphs) is summarized by Brenner et al. and the Cenozoic nannofossil biostratigraphy by Siesser and Bralower.

\section{Cruise Syntheses}

There are two cruise synthesis papers in this volume: von Rad et al. cover the structural and paleoenvironmental evolution of Wombat Plateau from the Triassic syn-rift to the Cenozoic mature ocean stage; Haq et al. discuss the Cretaceous-Cenozoic structural and depositional evolution of the southern Exmouth Plateau. Both syntheses summarize all structural and sedimentological/stratigraphic papers, attempt sequence-stratigraphic interpretations, and apply a passive margin evolution approach.

\section{ACKNOWLEDGMENTS}

The authors are grateful to the other members of the shipboard scientific parties of ODP Legs 122 and 123, for the detailed shipboard work and for various discussions about the results. The paper was reviewed by Doug Ramsay of BMR, John Veevers of Macquarie University, Sydney, Peter Cook of the British Geological Survey, and Suzanne O'Connell of Wesleyan University, Connecticut, and we thank them all for their help. Most figures were drafted in the BMR drawing office, and the text was typed by Pat Burrell at BMR. We are grateful to Ursula Röhl (BGR) for her help in compiling and drawing Figure 14. Exon publishes with the permission of the Executive Director, Bureau of Mineral Resources, Canberra, Australia.

\section{REFERENCES}

Arthur, M., and Sediments and Ocean History Panel, 1986. Deep stratigraphic tests, Somali Basin, Exmouth Plateau etc. Unpubl. Rep., JOIDES/ODP Site Survey Data Bank, Proposal 211/B.

Audley-Charles, M. G., 1988. Evolution of southern margin of Tethys (North Australian region) from early Permian to late Cretaceous. In Audley-Charles, M. G., and Hallam, A. (Eds.), Tethys and Gondwana. Geol. Soc. Spec. Publ. London, 37:79-100.

Barber, P. M., 1982. Paleotectonic evolution and hydrocarbon genesis of the central Exmouth Plateau. APEA J., 22(1):131-144.

1988. The Exmouth Plateau deep water frontier: a case history. In Purcell, P. G., and Purcell, R. R. (Eds.), The North West Shelf, Australia: Proc. Pet. Expl. Soc. Aust. Symp., 173187.

Boillot, G., Winterer, E. L., Meyer, A. W., et al., 1987. Proc. ODP, Init. Repts., 103: College Station, TX (Ocean Drilling Program).

Boote, D.R.D., and Kirk, R. B., 1989. Depositional wedge cycles on evolving plate margin, western and northwestern Australia. AAPG Bull., 73:216-243.

Bradshaw, M. T., Yeates, A. N., Beynon, R. M., Brakel, A. T., Langford, R. P., Totterdell, J. M., and Yeung, M., 1988. Paleogeographic evolution of the North West Shelf Region. In Purcell, P. G., and Purcell, R. R. (Eds.) The North West Shelf, Australia: Proc. Pet. Expl. Soc. Aust. Symp., 29-54.

Cande, S. C., and Mutter, J. C., 1982. A revised identification of the oldest sea-floor spreading anomalies between Australia and Antarctica. Earth Planet. Sci. Lett., 58:151-161.

Cockbain, A. E., 1989. The North West Shelf. APEA J., 29:529-545.

Dewey, J. F., 1988. Lithospheric stress, deformation and tectonic styles: the disruption of Pangaea and the closure of Tethys. In Audley-Charles, M. G., and Hallam, A. (Eds.), Tethys and Gondwana. Geol. Soc. Spec. Publ. London, 37:23-40.

Erskine, R., and Vail, P. R., 1988. Seismic stratigraphy of the Exmouth Plateau. In Bally, A. W. (Ed.), Atlas of Seismic Stratigraphy (Vol. 2). AAPG Stud. in Geol., 27:163-173.

Exon, N. F., von Rad, U., and von Stackelberg, U., 1982. The geological development of the passive margins of the Exmouth Plateau off northwest Australia. Mar. Geol., 47:131-152.
Exon, N. F., and Willcox, J. B., 1978. Geology and petroleum potential of the Exmouth Plateau area off Western Australia. AAPG Bull., 62:40-72.

1980. The Exmouth Plateau: stratigraphy, structure and petroleum potential. Bull. Bur. Miner. Resour. Geol. Geophys. Aust., No. 199.

Exon, N. F., and Williamson, P. E., 1988. Preliminary post-cruise report, Rig Seismic Research Cruises 7 \& 8: sedimentary basin framework of the northern and western Exmouth Plateau. Bur. Min. Resour. Aust. Rec., 1988/30.

Falvey, D. A., and Mutter, J. C., 1981. Regional plate tectonics and the evolution of Australia's passive continental margins. BMR J. Aust. Geol. Geophys., 6:1-29.

Falvey, D. A., and Veevers, J. J., 1974. Physiography of the Exmouth and Scott Plateaux, Western Australia, and adjacent northeast Wharton Basin. Mar. Geol., 17:21-59.

Fullerton, L. G., Sager, W. W., and Handschumacher, D. W., 1989. Late Jurassic-Early Cretaceous evolution of the eastern Indian Ocean adjacent to Northwest Australia. J. Geophys. Res., 94:2937-2953.

Haq, B. U., Hardenbol, J., and Vail, P. R., 1987. Chronology of fluctuating sea levels since the Triassic. Science, 235:1156-1167.

Haq, B. U., von Rad, U., O'Connell, S., et al., 1990. Proc. ODP, Init. Repts., 122: College Station, TX (Ocean Drilling Program).

Heirtzler, J. R., Cameron, P., Cook, P. J., Powell, T., Roeser, H. A., Sukardi, S., and Veevers, J. J., 1978. The Argo Abyssal Plain. Earth Planet. Sci. Lett., 41:21-31.

Hocking, R. M., Moors, H. T., and van der Graaff, W.J.E., 1987. The geology of the Carnarvon Basin, Western Australia. Bull.-Geol. Surv. West. Aust., No. 133.

Horstman, E. L., and Purcell, P. G., 1988. The offshore Canning Basin-a review. In Purcell, P. G., and Purcell, R. R. (Eds.), The North West Shelf, Australia: Proc. Pet. Expl. Soc. Aust. Symp., 253-258.

Larson, R. L., 1977. Early Cretaceous breakup of Gondwanaland off Western Australia. Geology, 5:57-60.

Larson, R. L., Mutter, J. C., Diebold, J. B., Carpenter, G. B., and Symonds, P. A., 1979. Cuvier Basin: a product of ocean crust formation by Early Cretaceous rifting off western Australia. Earth Planet. Sci. Lett., 45:105-114.

Ludden, J. N., Gradstein, F. M., et al., 1990. Proc. ODP, Init. Repts., 123: College Station, TX (Ocean Drilling Program).

Markl, R. G., 1974. Evidence for the breakup of eastern Gondwanaland by the Early Cretaceous. Nature, 251:196-200.

1978. Basement morphology and rift geometry near the former junction of India, Australia and Antarctica. Earth Planet. Sci. Lett., 39:211-225.

Mutter, J. C., and Larson, R., 1987. Repositioning of Site EP-2 to EP-12, Exmouth Plateau, based on results of two-ship seismic experiments. Unpubl. Rep., JOIDES/ODP Site Survey Data Bank.

Mutter, J. C., Larson, R. L., and Northwest Australia Study Group, 1989. Extension of the Exmouth Plateau, offshore northwestern Australia: deep seismic reflection/refraction evidence for simple and pure shear mechanisms. Geology, 17:15-18.

Mutterlose, J., in press. Early Cretaceous belemnites from the East Indian Ocean and their paleobiogeographic implications. In Gradstein, F. M., Ludden, J. N., et al., Proc. ODP, Sci. Results, 123: College Station, TX (Ocean Drilling Program).

Ogg, J. G., Kodama, K., and Wallick, B. P., in press. Lower Cretaceous magnetostratigraphy and paleolatitudes off Northwest Australia (ODP Site 765 and DSDP Site 261, Argo Abyssal Plain, and ODP Site 766, Gascoyne Abyssal Plain). In Gradstein, F. M., Ludden, J. N., et al., Proc. ODP, Sci. Results, 123: College Station, TX (Ocean Drilling Program).

Powell, D. E., 1976. The geological evolution and hydrocarbon potential of the continental margin off northwest Australia. APEA J., 16(1):13-24.

Purcell, P. G., and Purcell, R. R. (Eds.), 1988. The North West Shelf, Australia: A Case History: Proc. Pet. Expl. Soc. Aust. Symp.

Quilty, P. G., 1990. Triassic and Jurassic foraminiferid faunas, northern Exmouth Plateau, eastern Indian Ocean. J. Foraminiferal Res., 20:349-367. 
Sager, W. S., Fullerton, L. G., Buffler, R. T., and Handschumacher, D. W., in press. Argo Abyssal Plain magnetic lineations revisited: implications for the onset of seafloor spreading and tectonic evolution of the eastern Indian Ocean. In Gradstein, F. M., Ludden, J. N., et al., Proc. ODP, Sci. Results, 123: College Station, TX (Ocean Drilling Program).

Scotese, C. R., 1986. Phanerozoic reconstructions: a new look at the assembly of Asia. Univ. Texas Inst. Geophys. Tech. Rep., No. 66.

Sengör, A.M.C., 1985. The story of Tethys: how many wives did Oceanos have? Episodes, 8:3-12.

Struckmeyer, H.I.M., Yeung, M., and Bradshaw, M. T., 1990. Mesozoic palaeogeography of the northern margin of the Australian plate and its implications for hydrocarbon exploration. In Carman, G. J., and Carman, Z. (Eds.), Petroleum Exploration in Papua New Guinea. Proc. First PNG Petroleum Convention, Port Moresby, 137-152.

Veevers, J. J., 1988. Morphotectonics of Australia's north-western margin: a review. In Purcell, P. G., and Purcell, R. R. (Eds.), The North West Shelf, Australia: Proc. Pet. Expl. Soc. Aust. Symp., 19-27.

Veevers, J. J., Heirtzler, J. R., et al., 1974. Init. Repts. DSDP, 27: Washington (U.S. Govt. Printing Office).

von Rad, U., and Exon, N. F., 1983. Mesozoic-Cenozoic sedimentary and volcanic evolution of the starved passive continental margin off northwest Australia. In Watkins, J. S., and Drake, C. L. (Eds.), Studies in Continental Margin Geology: AAPG Mem., 34:253281.

von Rad, U., Exon, N. F., Symonds, P. A., and Willcox, J. B., 1984. Ocean drilling in the Exmouth and Wallaby Plateaus and Argo Abyssal Plain, E. Indian Ocean. Unpubl. Rep., JOIDES/ODP Site Survey Data Bank, Proposal 121/B.

von Rad, U., Exon, N. F., Williamson, P., and Boyd, R., 1986. Revision of ODP Proposal 121/B (ODP Leg Exmouth PlateauArgo Abyssal Plain) after the site survey by BMR's Rig Seismic Cruises 55 and 56 (March-May 1986). Unpubl. Rep., JOIDES/ODP Site Survey Data Bank, Proposal 121/B (revised).

von Rad, U., Schott, M., Exon, N. F., Mutterlose, J., Quilty, P., and Thurow, J., 1990. Petrography and microfacies of Mesozoic sedi- ments and volcanic rocks, dredged from the northern Exmouth Plateau during Rig Seismic-56 Cruise (1986). BMR J. Aust. Geol. Geophys., 11:449-476.

von Rad, U., Thurow, J., Haq, B. U., Gradstein, F., Ludden, J., and ODP Leg 122/123 Shipboard Scientific Parties, 1989. Triassic to Cenozoic evolution of the NW Australian continental margin and the birth of the Indian Ocean (preliminary results of ODP Legs 122 and 123). Geol. Rundsch., 78:1189-1210.

von Stackelberg, U., Exon, N. F., von Rad, U., Quilty, P., Shafik, S., Beiersdorf, H., Seibertz, E., and Veevers, J. J., 1980. Geology of the Exmouth and Wallaby Plateaus off northwest Australia: sampling of seismic sequences. BMR J. Aust. Geol. Geophys., 5:113140.

Weissel, J. K., and Hayes, D. E., 1974. The Australian-Antarctic discordance: new results and implications. J. Geophys. Res., 79:2579-2587.

Willcox, J. B., and Exon, N. F., 1976. The regional geology of the Exmouth Plateau. APEA J., 16(1):1-11.

Williamson, P. E., Exon, N. F., Haq, B. U., von Rad, U., O'Connell, S., and Leg 122 Shipboard Scientific Party, 1989. A Northwest Shelf Triassic reef play: results from ODP Leg 122. APEA J., 29(1):328-344.

Williamson, P. E., and Falvey, D. A., 1988. Preliminary post-cruise report, Rig Seismic research cruises 7 and 8: deep seismic structure of the Exmouth Plateau. BMR Rec., 1988/31.

Williamson, P. E., Swift, M. G., Kravis, S. P., Falvey, D. A., and Brassil, F., 1990. Permo-Carboniferous rifting of the Exmouth Plateau region (Australia): an intermediate plate model. In Pinet, B., and Bois, C. (Eds.), The Potential of Deep Seismic Profiling for Hydrocarbon Exploration: Arles (Editions Technip), 237-248.

Wright, A. J., and Wheatley, T. J., 1979. Trapping mechanisms and the hydrocarbon potential of the Exmouth Plateau. APEA J., 19:19-29.

Date of initial receipt: 30 August 1990

Date of acceptance: 2 March 1991

Ms 122B-194 